\title{
PRINCIPLES OF ADIPOBIOLOGY: A GENTLE INTRODUCTION
}

\section{George N. Chaldakov*}

Department of Anatomy and Cell Biology, Medical University, Varna, Bulgaria and Institute for Advanced Study, Varna, Bulgaria

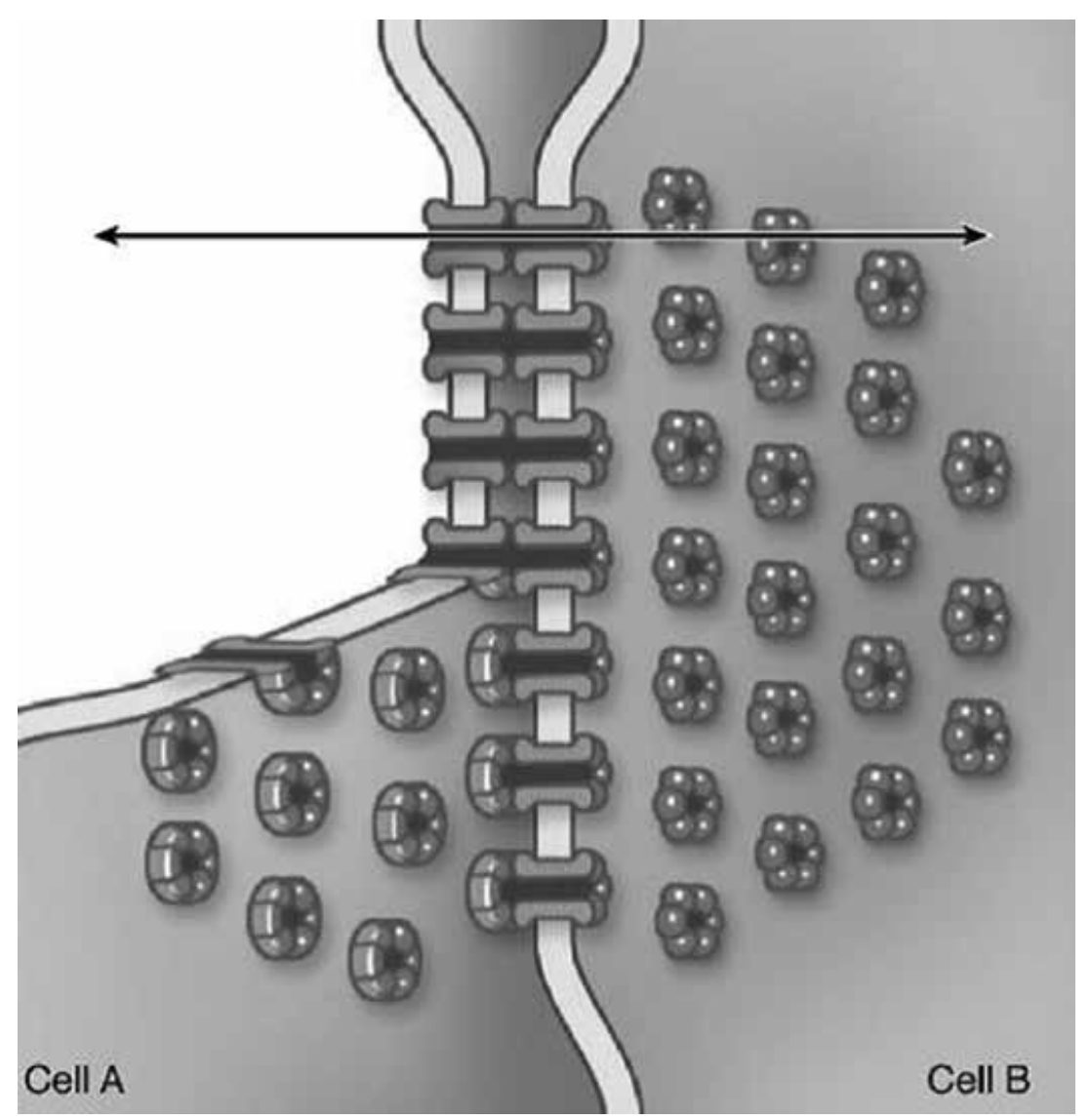

Figure 1. Schematic view of cell-to-cell interactions via nexuses (gap junctions, channel junctions, communicating junctions, macula communicans) between the neibouring Cell A and Cell B, intercellular space of $2-4 \mathrm{~nm}$. One channel of nexus is composed of two connexons (or hemichannels). The hexagonal structure of connexons (cross sectioned) consisting of six proteins termed connexins - $\mathrm{Cx}$ ) is evident; an arrow runs through one of the chanells. One nexus consists of about 100 connexons. (*Grosely R, Sorgen PL. A history of gap junction structure: Hexagonal arrays to atomic resolution. Cell Commun Adhes 2013; 20. DOI:10.3109/15419061.2013.775256 *Wright JA, Richards T, Becker DL. Connexins and diabetes. Cardiol Res Pract 2012; 2012: 496904. DOI:10.1155/2012/496904)

*Received 2 June 2019, revised 10 June 2019, accepted 11 June 2019.

Correspondence to: Dr George N. Chaldakov, Department of Anatomy and Cell Biology, Medical University, BG-9002 Varna, Bulgaria

Mobile phone: +359888679204

E-mail: chaldakov@yahoo.com - to keep students-to-teacher communicating junctions alive and kicking (Fig. 1) 


\section{Prologue}

Student - Latin, studeo - devoted to do something; studium eager, passion, study.

Teacher - To be a teacher is profound responsibility.

Paraphrasing Emily Dickinson's To be a flower is profound responsibility .

\section{DECALOGUE FOR THE STUDENT*}

1. He who learns, he will succeed. (Bulgarian proverb)

2. Forward! Science is a sun, / which in our souls shines! (a traditional song of Bulgarian students and teachers) - not only on May 24, the Bulgarian National Day of Cyrillic Alphabet and Culture, but continuously throughout life (LLP Lifelong Learning Program; also, Laboratory, Library, Pub; CME - Continuing Medical Education).

3. Follow didactic cascade: from information to knowledge to way of thinking. Feel the knowledge like you feel your mother tongue. Translate the information of cellular molecules, structures and functions (MSF) into knowledge of the pathogenesis of Diseases and their Prevention and Therapy (DPT); that is a creative journey from bench-tobedside (BtB). Remember: There are no departments and clinics within the cell.

4. Learning without thinking is useless. Thinking without learning is dangerous (Confucius). Be thinker and doer, both.

5. Human cognitive potential is symbiosis of thoughts and emotions. Think outside the box.

6. Imagination is more important than knowledge because knowledge is limited (Albert Einstein) - stream of associations is an essential tool of a creative learning.

7. Develop moral reflexes - mutual respect and love for each other, create and enjoy brain-and-heart friend/ship (BHF).

8. Follow your parents' advice: WHAT DID I ARRIVE HERE FOR? - to study first, then rejoice - the reverse chronology is meaningless.

9. Healthy lifestyle and good education can ensure your quality of life (QoL).

10. Stay tuned, wise and independent (sapere aude), have the intellectual courage to cross (at least once) at a red light the road of science to make your own green path on it. To achieve your Eureka effects.

\section{Then you can say: Vox Studentium vox Dei!}

*From: Chaldakov GN. Homo Janus. Psychology and Psychopathology (not only) of Bulgarians. Publissays and science-infiction. Third revised and enlarged edition. 2018. Morski Sviat Publisher, Varna, Bulgaria. ISBN 978-619-7328-12-7

\section{Introduction}

The biological research has already provided a wealth of knowledge about individual cellular components and their functions. Despite its success, it is increasingly clear that most biological phenomena arise from multiplex interactions between the cell's numerous constituents, such as molecules and structures (organelles). Therefore, a key challenge for cell biology and adipobiology at present is to understand the dynamics of the cell-to-cell and cell-to-extracellular matrix (ECM; hereafter, matrix) interactions (communications, signaling) that contribute to the biological life ( ${ }^{*}$ Chaldakov GN. Cell Biology. 2th updated and enlarged edition - in Bulgarian. University Press, Varna, Bulgaria. 2014. ${ }^{*}$ Chaldakov GN. Biomorphogenic principles of cell-matrix biology: A plectics insight. Biomed Rev 2019;30:143-148*Also a cell biology lecture in YouTube: https://youtu.be/cNBY_ykbK3Q

and adipobiology lecture, both presented in English:

https://www.youtube.com/watch?v=QrXLA4UsQnw

https://www.youtube.com/watch?v=a36MeFO1L8I).

My didactics is focused on research-based and associative teaching applying both stream of associations (SOA) and keep it short and simple (KISS)*

If you give a man a fish, you feed him for a day. If you teach him to fish, you feed him for a lifetime.

\section{Chinese saying}

In the didactics and epistemology this is "to know how", not only "to know that".

"The learning outcomes have to be on the level of analyzing, evaluating and creating, not only on the level of remembering, uderstading and applying. To know about information are outcomes of surface learning versus deep learning approach" $\left({ }^{*}\right.$ Isa Jahnke. Digital Didactical Designs in CrossActionSpace. 2015).

*In the "stream", KISS also means KISS gene - encoding for kisspeptin-1, a biomolecule involved in reproductive and cancer biology. And may stand for Ockhams razor, the idea attributed to English philosopher William of Ockham (1287-1347). That is the problem-solving principle: „Entities should not be multiplied without necessity." In the same stream are Aristotle's own words: Nature never makes anything that is superfluous written in his book De Partibus Animalium.

\section{My didactics aims at:}

(i) Inflaming the curiosity of students (and teachers), remembering Plato's "Philosophy begins in wonder", modifying herein as "Science and education begin in wonder." 
(ii) Teaching students how information becomes knowledge and way of thinking in the biomedicine (and in the life).

(iii) Transforming the knowledge of cellular MSF into knowledge of DPT - that is Bench-to-Bedside (BtB), Translational Cell Biology.

In the SOA, see Donald Hebb's 1949 book The Organization of Behavior about associative learning based on cell assembly theory, also known as Hebb's rule (Cell that fire together, wire together, that sounds like the Latin Repetitio est mater studiorum). Hebbian learning account of mirror neurons in the brain, an influential behavioral theory. These neurons „mirror" the actions and intentions of the other - they fire both when an individual performs an action and when the individual sees or hears another perform a similar action $\left({ }^{*}\right.$ Iacoboni M. Grasping the intentions of others with one's own mirror neuron system. PLOS Biology. 2005;3 (3): e79. DOI:10.1371/ journal.pbio.0030079).

\section{Abbreviations and terms}

(listed associatively, not alphabetically)

MSF, molecules, structures, functions

DPT, disease, prevention, therapy

ECM, extracellular matrix (briefly, matrix)

BtB, bench-to-bedside

CME, continuing medical education

D (or Da), D, kD, MD, GD. Dalton, named after John

Dalton, is unified atomic mass unit; unit of molecular weight of proteins, DNA, RNA and other large biopolymers -

kilodaltons $(\mathrm{kD})$, megadaltons (MD), and gigadalton (GD).

$\mathrm{Cx}$, connexin - the composer of nexuses as shown in

Figure 1 .

Cx32, Cx36, Cx43, connexins with molecular weight of 32,

$36,43 \mathrm{kD}$, respectively

AT, adipose tissue

WAT, white adipose tissue

BAT, brown adipose tissue

BRITE, brown-in-white adipose tissue (beige AT, beige adipocytes)

\section{Adipose-derived neurotrophic factors (Table 1)}

Adipokines, signaling proteins secreted by adipose tissue cells (see below)

Myokines, signaling proteins secreted by skeletal muscles, the largest organ determining body's insulin sensitivity and metabolic homoeostasis (Table 2).

Myoadipokines, myokines (irisin, NGF, BDNF) also secreted by adipose cells.

Osteokines, protein sectreted by osteocytes (bone) cells fibroblast growth factor 23 (FGF 23), ostecalcin
Table 1. A selected list of adipose-derived neurotrophic factors

Neurotrophins (NGF, nerve growth factor, BDNF, brain-derive neurotrophic factor, neurotrophins (NT-3, NT-4/5, NT-6, NT-7) Glial cell line-derived neurotrophic factor (GDNF)

Ciliary neurotrophic factor (CNTF)

Vascular endothelial growth factor (VEGF)

Leptin, Adiponectin, Metallothioneins

Meteorin-like (Metrnl), also known as Cometin, Subfatin,

Interleukin 39)

Neprilysin (NEP) - $\beta$-amyloid peptide (A $\beta$ )-degrading enzyme

Table 2. A selected list of myokines

Irisin*, Visfatin, Interleukin (IL-4, IL-6, IL-7, IL-15)

Brain-derived neurotrophic factor (BDNF), Nerve growth factor (NGF)

Myonectin, Myostatin, Leukaemia inhibitory factor (LIF), Atrial natriuretic peptide (ANP)**

* Named after the Greek messenger goddess Irisi. Irisin derives from the cleavage of fibronectin type III domain-containing protein 5 (FNDC5)

** Promotes kidney excretion of salt and water. ANP is secreted by atrial cardiomyocytes of the heart.

\section{The better you know Cell Biology, the better will know Adipobiology}

The present continuing medical education (CME) is for all medical, dental and cell biology students, also medical and dental doctors and university teachers who are loaded with love-of-knowledge (in Bulgarian, lyuboznanie; in Greek, epistemophilia - episteme - knowledge, philia - love, friendship). This CME embodies a personal didactic philosophy I hope to be appreciated by the readers. And enjoy their lyuboznanie.

From Latin principium means "first, foremost" - that is the foundation of one's knowledge $\left({ }^{*}\right.$ Chaldakov GN. Biomorphogenic principles of cell-matrix biology: A plectics insight. $\mathrm{Bi}$ omed Rev 2019; 30:143-148 *Torday JS, Rehan VK. Evolutionary Biology, Cell-Cell Communication, and Complex Disease. 2012. John Wiley \& Sons, Inc. DOI:10.1002/9781118130452).

Certainly, we should know the scientific facts, but I believe that they are required primarily to incorporate them into principles, knowledge, hypotheses, theories, and paradigms. Quite similar to how molecules incorporate their properties into the structure they build up and properties become structure's function.

I try to provide students with more integrative and conceptual view of triarchic nature of cell-and-matrix MSF (Fig. 2). 


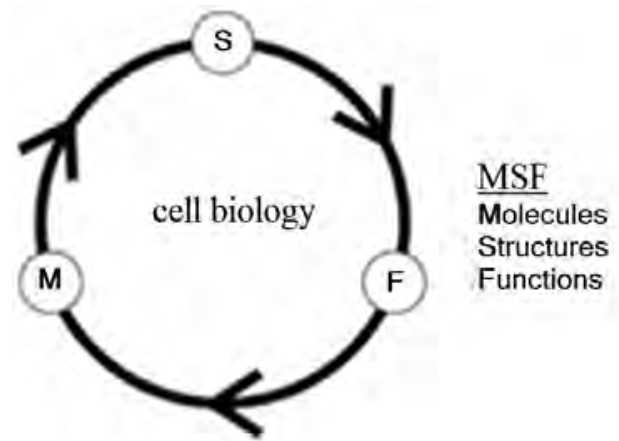

Figure 2. A drawing illustrating MSF-based teaching Cell Biology. This may enable students understanding the triarchic nature of the life of cells and tissues. From: Chaldakov GN. Cell Biology. $2^{\text {nd }}$ edition. 2014.

\section{General principle of cell and tissue biology}

The cells-and-matrix is molecular, structural and functional (MSF) unit of multicellular organisms

It is a teaching cliche that cells are "unit of life" and "building blocks of life" (even in *Bruce Alberts, et al. Molecular Biology of the Cell. 5th edition, 2008). However, the cells (except blood and lymph circulation cells) are surrounded and linked - both structurally and functionally - with ECM (matrix). When a cell is separated from the matrix, it becomes "homeless" and dies - anoikiya, a type of programmed cell death.

Understanding the cells separately from the matrix is conceptually wrong, because not only is the matrix a product of the cell, but it is also connected by the plasmalemma (plasma membrane, cell surface) via receptor-ligand interactions. In effect, that leads to cell-matrix communication (signalling) with each other (Fig. 3, 4, Table 3).

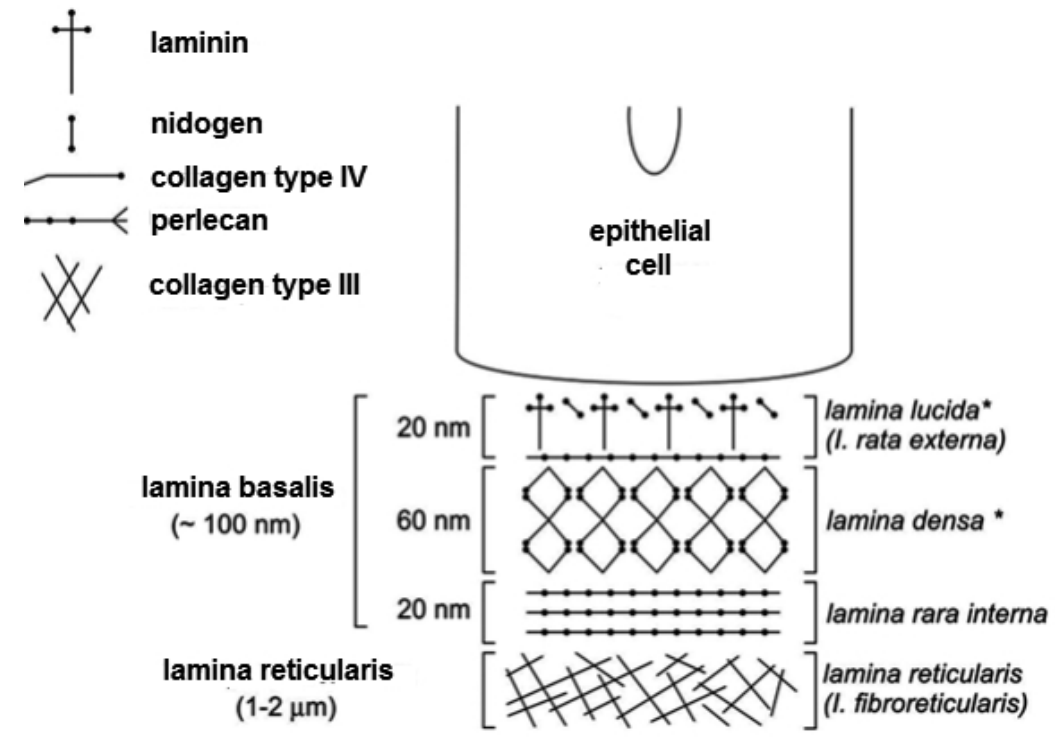

Figure 3. Schematic representations of epithelial cell-basal lamina unity; basal lamina (lamina basalis) is a matrix component. Molecular architecture of basal lamina and lamina reticularis is depicted. From: Chaldakov GN. Biomorphogenic principles of cell-matrix biology: A plectics insight. Biomed Rev 2019; 30:143-148.
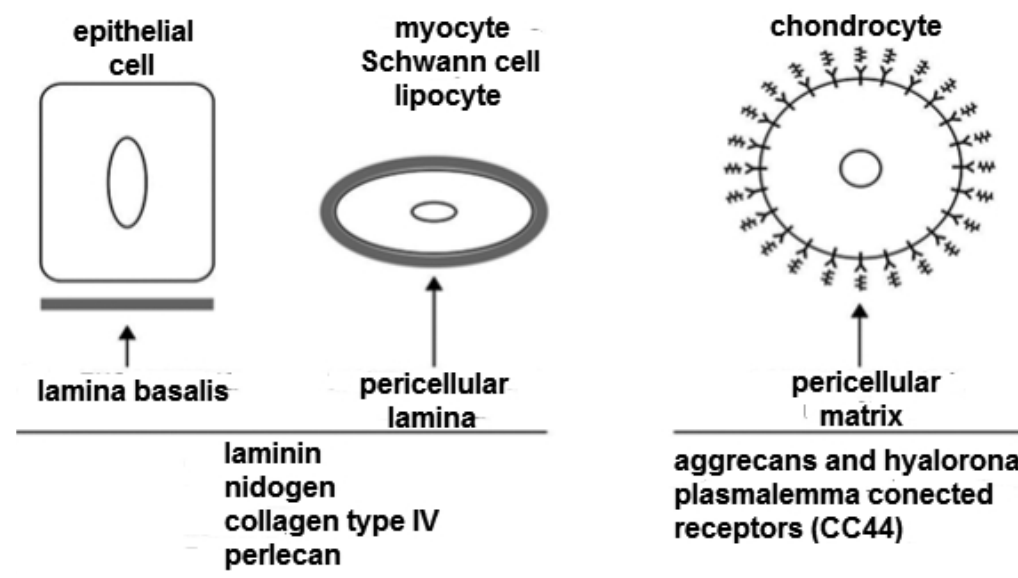

aggrecans and hyaloronate plasmalemma conected receptors (CC44)

Figure 4. Schematic representations (i) cell-basal lamina unity in epithelial cell, myocyte, Schwann cell, and lipocyte (adipocyte), and (ii) pericellular matrix of the chondrocyte. Sorry, CC44 indicated in chondrocyte should be CD44 (cluster of differentiation-44), a multifunctional plasmalemmal receptor expressed in many cell types, not only chondrocytes, and involved in cell adhesion and migration (in case of cancer cells - metastases). CD44 is also referred to as HCAM (homing cell adhesion molecule). From: Chaldakov GN. Biomorphogenic principles of cell-matrix biology: A plectics insight. Biomed Rev 2019; 30:143-148 
Table 3. Examples of cells having basal lamina

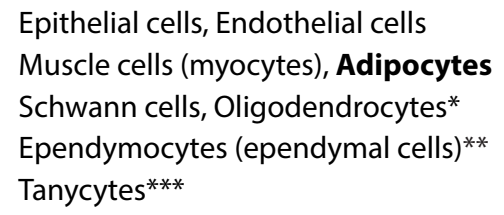

* Myelinogenesis is the process of formation of myelin sheath of axons. Schwann cells (named after Theodor Schwann) are glial cells whose main function is myelinogenesis of axons in the peripheral nervous system. Oligodendrocytes (Greek, cells with a few branches), are a type of glial cells whose main function is myelinogenesis of axons in the central nervous system Hence, Schwann cells and oligodendrocytes are myelinogenic cells.

** Type of glial cells lining of the ventricular system of the brain and the central canal of spinal cord, involved in the production of cerebrospinal fluid (CSF), also serve as a reservoir for neuroregeneration, because of their potentials as neural stem cells (*Tonchev AB, Yamashima T, Zhao L, Okano HJ, Okano H. Proliferation of neural and neuronal progenitors after global brain ischemia in young adult macaque monkeys. Mol Cell Neurosci 2003; 23(2):292-301. DOI:10.1016/S1044-7431(03)000587).

*** From Greek, tanus means elongated, tanycytes are special ependymal cells found in the third ventricle of brain, and on the floor of fourth ventricle - they have processes extending deep into the hypothalamus. Their function is to transfer chemical signals from the cerebrospinal fluid to the brain.

\section{Principles of Adipobiology}

- Can you understand why my car can not move? - asked me a lady.

- Madam, I do not know how a car can move at all - replied the Nobel laureate-1937 Albert Szent-Györgyi. Retrospect and Apology. In: Milhorat AT, editor. Exploratory Concepts in Muscular Dystrophy and Related Disorders. New York, Excerpta Medica Foundation, 1966; pp 112-114.

\section{Abbreviations and terms continued}

UCP, uncoupling protein 1-3, signature proteins located in the inner mitochondrial membrane of brown and beige adipocytes

beta-3 adrenergic receptor ( $\beta_{3}$ adrenoreceptor), its activation leads to lipolysis and thermogenesis, a signature function of BAT

LD, lipid droplets (liposomes, adiposomes)

LR, lipid rafts, plasmalemmal nanodomains with highest density of both cholesterol and receptors; along with primary (single, $9+0$ microtubule) cilia and caveolae, LR are receptor clustering centers (RCC) of the cell.
BMI, body mass index $\left(\mathrm{kg} / \mathrm{m}^{2}\right)$

TOFI, thin outside, fat inside

TOTI, thin outside, thin inside

FOTI, fat outside, thin inside

FOFI, fat outside, fat inside

PAAT, periadventicial adipose tissue (tunica adiposa) of blood vessels

FTO, fat mass and obesity-associated protein, an enzyme encoded by FTO gene,

its variants associate with obesity

mTOR, mammalian target of rapamycin

NCD, noncommunicable diseases

CMD, cardiometabolic diseases

CVD, cardiovascular dieases

T2DM, type 2 diabetes mellitus

GLUT, glucose transporters, GLUT4 is the major GLUT of adipocytes and skeletal muscles

NAFLD, nonalcoholic fatty liver disease

$\mathrm{NASH}$, non-alcoholic steatohepatitis

\section{The way from Magister dixit to Doctor dixit}

Nothing a cell does is without significance.

Denys N. Wheatley

$\left({ }^{*}\right.$ Wheatley DN. "Rediscovery" of a forgotten organelle, the primary cilium:

The root cause of a plethora of disorders.

Biomed Rev 2013; 24:1-7)

Students learning Adipobiology (as well as Cell Biology) have to ask Qs and give As: Which Molecules, how, where (cell, extracellular matrix, tissue, organ), when (interphase, mitosis), what Structures they form, and what Functions perform.

Hence, the more the students know MSF, the better they may understand DPT - the main mission of the physician (MD, medical doctor).

Today, the biggest and costliest biosocial burden is the mortality from noncommunicable diseases (NCD), such as cardiometabolic diseases (CMD - atherosclerosis, hypertension, obesity, type 2 diabetes mellitus, and metabolic syndrome) and oncological diseases, all of them linked to the biology of adipose tissue (AT).

Imagine a world in which everyone knows only part of the alphabet.

Jamey Marth ( ${ }^{*}$ Marth J. A unified vision of the building blocks of life. Nat Cell Biol 2008; 10(9):1015-1016.

DOI:10.1038/ncb0908-1015.)

The language of adipobiology (lingua adipobiologica) has its 
own alphabet, words, grammar, semantics, and syntax - to anable students (and teachers) to arrange the respective words in sentences and then, in novels (and poems) of cell-andmatrix life.

\section{Lingua adipobiologica}

Adipobiology, study of MSF of AT in health and disease (a term introduced by ${ }^{\star}$ Chaldakov GN, Stankulov IS, Hristova MG, Ghenev PI. Adipobiology of disease: adipokines and adipokine-targeted pharmacology. Curr Pharm Des 2003; 9:10231031. DOI:10.2174/1381612033455152).

Adiposcience, study of AT termed as such by Yuji Matsuzawa and colleagues ( ${ }^{\star}$ Obata Y, Maeda N, Yamada Y, Yamamoto K, Nakamura S, Yamaoka M, et al. Impact of visceral fat on gene expression profile in peripheral blood cells in obese Japanese subjects. Cardiovasc Diabetol 2016; 15:159. DOI: 10.1186/ s12933-016-0479-1).

Adipokines (instead of adipocytokines; see below), AT cells-secreted signaling proteins (with another words, adipose-derived multifunctional proteins) (a term introduced by ${ }^{\star}$ Chaldakov GN, Fiore M, Ghenev PI, et al. Atherosclerotic lesions: possible interactive involvement of intima, adventitia and associated adipose tissue. Int Med J 2000;7:43-49).

Adipogenesis, differentiation of pre-adipocytes to mature adipocytes.

Adipopharmacology, AT-targeted study for drug discovery ( ${ }^{*}$ Töre F, Tonchev AB, Fiore M, Tuncel N, Aloe L, et al. From adipose tissue protein secretion to adipopharmacology of disease. Immun Endoc Metab Agents Med Chem 2007; 7: 149-155. DOI: $10.2174 / 187152207780363712{ }^{*}$ Chaldakov GN, Fiore M, Tonchev AB, Aloe L. Adipopharmacology, a novel drug discovery approach: a metabotrophic perspective. Lett Drug Design Discov 2006; 3:503-505).

Tunica adiposa, the outermost coat of blood vessel's wall; in brief, adiposa, like intima, media, adventitia $\left({ }^{\star}\right.$ Chaldakov GN, Fiore M, Ghenev PI, Tuncel N, Rancic G, et al. State-of-theartery: periadventitial adipose tissue (tunica adiposa). Biomed Rev 2009; 20: 41-44. DOI: 10.14748/bmr.v20.53 ${ }^{\star}$ Chaldakov GN, Beltowsky J, Ghenev PI, Fiore M, Panayotov P, et al. Adipoparacrinology - vascular periadventitial adipose tissue $(t u$ nica adiposa) as an example. Cell Biol Int 2012; 36 327-330. DOI: 10.1042/CBI2011042). Synonym: periadventitial adipose tissue (PAAT) ${ }^{\star}{ }^{\star}$ Stankulov IS, Aloe L, Ghenev PG, Manni L, Pavlov P, et al. PAAT: A path to atherosclerosis? Biomed Rev 2002;13:63-65).

Traditional view considers that the arterial wall is composed of three tissue coats (tunicae): intima, media, and adventitia. However, many blood vessels are consistently surrounded by
PAAT. Through paracrine (vasocrine) way, adiposa-derived mediators may contribute to various vascular functions such as contraction-relaxation, smooth muscle cell growth, inflammation and innervation, hence to „outside-in“ signaling pathway in CVD $\left({ }^{*}\right.$ Chaldakov GN, Fiore M, Ghenev PI, et al. Atherosclerotic lesions: possible interactive involvement of intima, adventitia and associated adipose tissue. Int Med J 2000; 7:43-49) (Fig. 5).

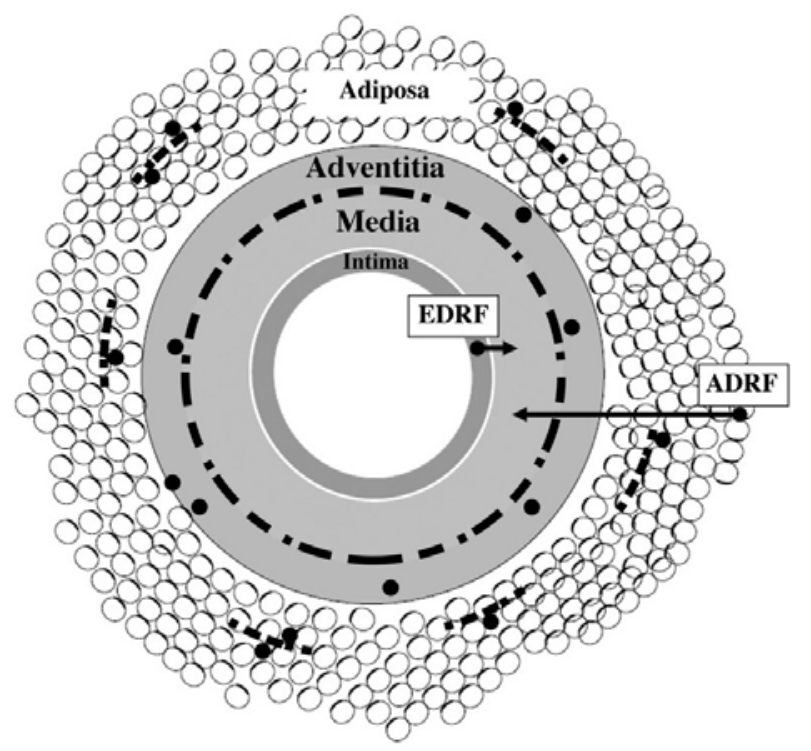

Figure 5. Schematic presentation of vascular wall composed of four tissue coats (tunicae): intima, media, adventitia, and adiposa. Arrows showthat tunica media is a target for both endothelium-derived relaxing factor (EDRF) and adipocytederived relaxing factor (ADRF) respectively. Discontinuous black line positioned at the adventitia-media border illustrates perivascular nerves. Small-sized discontinuous black lines located in tunica adiposa indicate adipose nerves. Black granules (except those linked to arrows) illustrate immune cells - their association with nerves and adipocytes is also depicted. From: Chaldakov GN, Fiore M, Ghenev PI, Beltowski J, Rancic G, Tuncel N, Aloe L. Triactome: neuro-immune-adipose interactions. Implication in vascular biology. Front Immunol 2014; DOI: 10.3389/fimmu.2014.00130

\section{Lingua adipobiologica continued}

Adipocrinology, a component of endocrinology

- Adipoendocrinology

- Adipoparacrinology $\left({ }^{\star}\right.$ Chaldakov GN, Stankulov IS, Fiore $\mathrm{M}$, et al. Adipoendocrinology and adipoparacrinology: emerging fields of study on the adipose tissue. Biomed Rev 2001; 12:31-39. ${ }^{*}$ Chaldakov GN, Tuncel N, Beltowski J, et al. Adipoparacrinology: an emerging field in biomedical research. Balkan Med J 2012; 29:2-9) 
Neuroadipocrinology (Neuroadipology) $\quad\left({ }^{*}\right.$ Chaldakov GN, Fiore M, Tonchev AB, Aloe L. Neuroadipology: a novel component of neuroendocrinology. Cell Biol Int 2010; 34:1051-1053)

Adipoimmunology $\left({ }^{\star}\right.$ Tunçel N, Yanev S, Atanassova P, Beltowski J, Aloe L.The mast cell: Another master in adipoimmunology. Adipobiology 2015; 7:15-19)

Homo obesus, the human obese (a term introduced by ${ }^{*}$ Chaldakov GN, Fiore M, Tonchev AB, et al. Homo obesus: a metabotrophin-deficient species. Pharmacology and nutrition insight. Cur Pharm Des 2007; 13: 2176-2179).

Diabesity, the human with both diabetes mellitus and obesity (a term introduced by ${ }^{\star}$ Astrup A, Finer N. Redefining type 2 diabetes: 'diabesity' or 'obesity dependent diabetes mellitus'? Obes Rev 2000; 1:57-59).

Adipocyte-derived relaxing factor (ADRF), a transferable relaxing factor released by PAAT that acts by the activation of $\mathrm{K}+$ channels in vascular smooth muscle cells. Other examples of ADRF are nitric oxide $(\mathrm{NO})$, hydrogen peroxide $\left(\mathrm{H}_{2} \mathrm{O}_{2}\right)$ and hydrogen sulfide $\left(\mathrm{H}_{2} \mathrm{~S}\right)\left({ }^{*}\right.$ Wojcicka G, Jamroz-Wisniewska A, Attanasova $\mathrm{P}$, et al. Differential effects of statins on endogenous $\mathrm{H}_{2} \mathrm{~S}$ formation in perivascular adipose tissue. Pharmacol Res 2011; 63:68-76. DOI:10.1016/j. phrs.2010.10.011).

Epicardial adipose tissue, AT surrounding the heart and coronary arteries $\left({ }^{*}\right.$ Chaldakov GN, Stankulov IS, Aloe L. Subepicardial adipose tissue in human coronary atherosclerosis: another neglected phenomenon. Atherosclerosis 2001; 154:237-238 * Iacobellis G, Bianco AC. Epicardial adipose tissue: emerging physiological, pathophysiological and clinical features. Trends Endocrinol Metab 2011;22:450-457).

Periaortic adipose tissue, AT surrounding the aorta. Its amount correlates with visceral adipose tissue, an adipse depot with important implications for cardiovascular disease. It can be subdivided into (i) thoracic periaortic AT, which refers to BAT (sanogenic) surrounding the thoracic aorta; and (ii) abdominal periaortic AT, which refers to WAT (pathogenic) surrounding the abdominal aorta (Fig. 6). There is not a clear division in pure BAT or pure WAT. The infiltration of white adipocytes can be found in BAT (whitening of BAT, a pathogenic phenomenon) and of brown adipocytes in WAT (browning of WAT, a sanogenic phenomenon). ( ${ }^{\star}$ Blirando K. Epigenetic regulation of adipocytes phenotype: Implication for perivascular adipose tissue contribution to cardiometabolic diseases. Adipobiology 2016; 8:19-34. ${ }^{*}$ Rancic G, Fiore M, Tuncel N, Hiriart M, et al. PVAT and atherogenesis: a crossroad of white and brown adipobiology. Adipobiology 2016; 8:35-38).

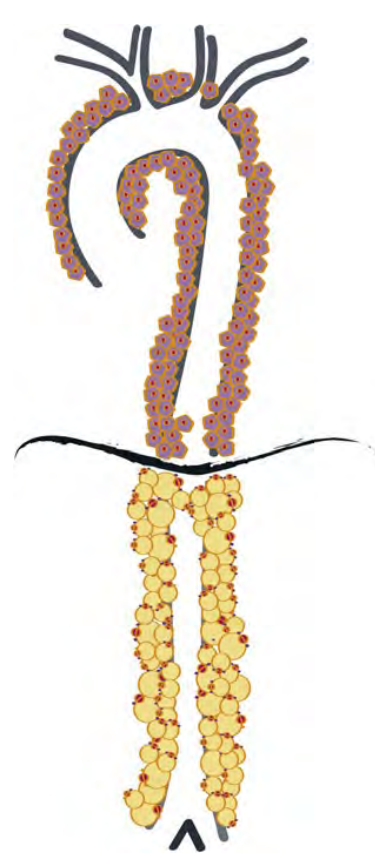

Figure 6. Regional differences in periaortic PAAT are related to distinct functions and pathophysiological complications. Regional differences in PAAT might also appear within different regions of the same vessel. Thoracic periaortic PAAT exhibits BAT feature, which is implicated sanogenically in vascular biology, thus protecting the vascular wall against atherosclerosis and hypertension. However, abdominal periaortic adipose tissue is WAT, expressing inflammatory adipokines. White PAAT is highly responsive to high-fat diet with a marked increase in the presence of atherosclerotic plaques and the development of aortic aneurysms. From: Gil-Ortega M, Somoza B, Huang Y, Gollasch M, FernándezAlfonso MS. Regional differences in perivascular adipose tissue impacting vascular homeostasis. Trends Endocrinol Metab 2015; 26(7):367-375. DOI:10.1016/j.tem.2015.04.003

\section{Lingua adipobiologica continued}

Yo soy yo y mi circunstancia

(I am I and my circumstance).

Jose Ortega y Gasset

Adipotoxicology, an adipocentric approach in molecular toxicology and epidemiology, the study of metabolism, release and effects of adipose-stored xenobiotics (foreign substances) in health and disease.

The human genome project's big promise was that it could improve our understanding of the pathogenesis and therapy of diseases. However, the genes have been found to account for only about $10 \%$ of diseases, and the remaining causes appear to be from environmental exposures, hence the exposome concept has emerged ( ${ }^{*}$ Wild CP. Complementing the genome with an "exposome": The outstanding challenge of environ- 
mental exposure measurement in molecular epidemiology. Cancer Epidemiol Biomarkers Prev 2005;14(8):1847-1850).

Homo sapiens is exposed to an overwhelming number of chemical contaminants circulating every day in the air, water, food, and general environment. The body is a well-equipped entity with capabilities to excrete water-soluble pollutants, but not as well-equipped to excrete some of the lipid-soluble xenobiotics. According to the European Environmental Agency in the late 1990's more than 100000 chemical compounds were registered in the European Catalogue of Commercialized Chemical Substances. The exposure to persistent organic pollutants (POP) may contribute to the pathogenesis of obesity and related diseases. These pollutants accumulate mainly in the AT. And xenobiotic-metabolizing cytochrome p450 (CYP) enzymes are expressed in AT. They can bioactivate carcinogenic polycyclic aromatic hydrocarbons and xenoestrogens ( ${ }^{*}$ Yanev S, Chaldakov GN. Adipose tissue: a master in toxicology. Adipobiology 2012; 4:59-66. DOI: 10.14748/adipo. v4.281.*Fruhbeck G, Chaldakov GN. Would-be-worlds of adipobiology in the exposome of globesity. Adipobiology 2012; 4: 107-110).

\section{Adipose tissue as a "toxicrine" organ} (a harmful xenobiotics site):

- Surface abundance of more than 80 billion adipocytes in adult men.

- Main lipid storage place; in obese person up to 50\% of his/ her weight is lipid.

- Preferable storage place for xenobiotics - more than 300 foreign chemicals have been identified in human AT and breast milk.

- Persistent organic pollutants (POP) and endocrine-disrupting chemicals (EDC) stored in AT can be negatively mobilized after rapid weight reduction, excessive exercise, emotional stress, etc.

- Mobilization of AT-stored xenobiotics might be obesogenic (pathogenic)

\section{Expert in the field:}

Stanislav Yanev, Laboratory of Drug Toxicology, Institute of Neurobiology, Bulgarian Academy of Sciences, Sofia, Bulgaria.

E-mail: stanislav_yanev@yahoo.com

\section{Never before has adipose tissue been so active}

Salutary (metabotrophic) adipokines ( ${ }^{*}$ Giamila Fantuzzi. The sound of health. Front Immunol 2014; DOI: 10.3389/ fimmu.2014.00351 *Yanev S, Aloe L, Fiore F, Chaldakov GN. Neurotrophic and metabotrophic potential of nerve growth factor and brain-derived neurotrophic factor: Linking. World J
Pharmacol 2013; 2: 92-99. DOI:10.5497/wjp.v2.i4.92).

Adipsin (also known as complement factor D - CFD), discovered in 1987 it is the first indentified adipose-secreted hormone, a member of the trypsin family of serine proteases, involved in the innate immune defense against infections, also insulin secretion and other metabolic functions ( ${ }^{\star}$ Lo JC, Ljubicic S, Leibiger B, Kern M, Leibiger IB, Moede T, et al. Adipsin is an adipokine that improves $\beta$ cell function in diabetes. Cell. 2014;158(1):41-53. DOI: 10.1016/j.cell.2014.06.005).

Leptin (Greek, leptos - thin), an adipokine with a pivotal significance for energy and lipid homeostasis and for other cellular processes (aslo see below).

Adiponectin, an anti-diabetic, anti-obesity, anti-inflammatory, anti-atherosclerotic, anti-aging adipokine (a multitarget adipokine; metaphorically, an "anti-kine"), a promisful factor for diverse therapeutic applications. In the blood rculation, adiponectin has three oligomeric forms, including a trimer (lowmolecular weight), hexamer (medium-molecular weight), and high-molecular weight (HMW) form. Among them, HMW adiponectin is the major active form as it displays greater insulin sensitizing and anti-inflammatory properties. Blood circulating adiponectin level in centenarians is associated with an advantageous metabolic phenotype, including higher highdensity lipoprotein (HDL) levels and negatively correlated with C-reactive protein, an inflammatory biomarker ( ${ }^{*}$ Yasumichi Arai Y,, Kei Kamide K, Hirose. Adipokines and aging: Findings from centenarians and the very old. Front Endocrinol 2019; DOI: 10.3389/fendo.2019.00142).

Sirtuins (SIRT), proteins encoded by the gene sir, silent information regulator (pronounced "sir"). The sirtuin family of proteins consists of seven members in mammals (SIRT 1-7) ( ${ }^{*}$ ali-Youcef N, Lagouge M, Froelich S, Koehl C, Schoonjans K, Auwerx J. Sirtuins: the ,magnificent seven', function, metabolism and longevity. Ann Med 2007;39(5):335-345). Sirtuins share nicotinamide adenine dinucleotide (NAD) dependency for their deacetylase activity. Nicotinamide phosphoribosyl-transferase (NAMPT) is NAD biosynthetic enzyme, incuding in AT. ( ${ }^{\star}$ Yoon MJ, Yoshida M, Johnson S, Takikawa A, Usui I, Tobe K, et al. SIRT1-mediated eNAMPT secretion from adipose tissue regulates hypothalamic NAD+ levels in mice. Cell Metab 2015; 21(5):706-717. DOI: 10.1016/j.cmet.2015.04.002).

Klotho, a transmembrane protein (the enzyme $\beta$-glucuronidase) and in a secreted, blood circulating form by ectodomain shedding of the membrane-bound form. Soluble Klotho has a variety of salutary effects, including being a potential aging suppressor ( ${ }^{\star}$ Kuro-o $\mathrm{M}$. Klotho and aging. Biochim Biophys Acta 2009; 1790: 1049-1058. DOI: 10.1016/j. 
bbagen.2009.02.005 ^Dërmaku-Sopjani M, Kolgeci S, Abazi S, Sopjani M. Significance of the anti-aging protein Klotho. Mol Membr Biol 2013; 30:369-385. DOI:10.3109/09687688.2013.83 7518). There are $\alpha$-Klotho, $\beta$-Klotho and $\gamma$-Klotho, the most studied being $a$-Klotho.

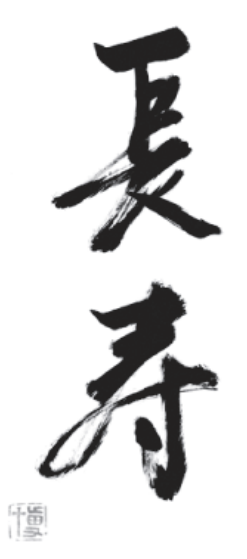

In ancient Greek mythology, Clotho (Spinner) is one of the three Moirai. She is responsible for spinning the thread of human life onto her Spindle.

In human biology, Klotho protein may indeed be one of the keys that could open the doors of longevity, presented herein as Chow-Ju (Japanese, Longevity is a Good Thing - Chow is long, Ju - something nice), a calligraphy by Professor Hiroshi Yamamoto, Director of Komatsu University, Komatsu, Ishikawa, Japan.

Neurotrophins (some of them also presented in Table 1) NGF discoved by Rita Levi-Montalcini (RLM). NGF is the prototypic member of the protein family of neurotrophins.

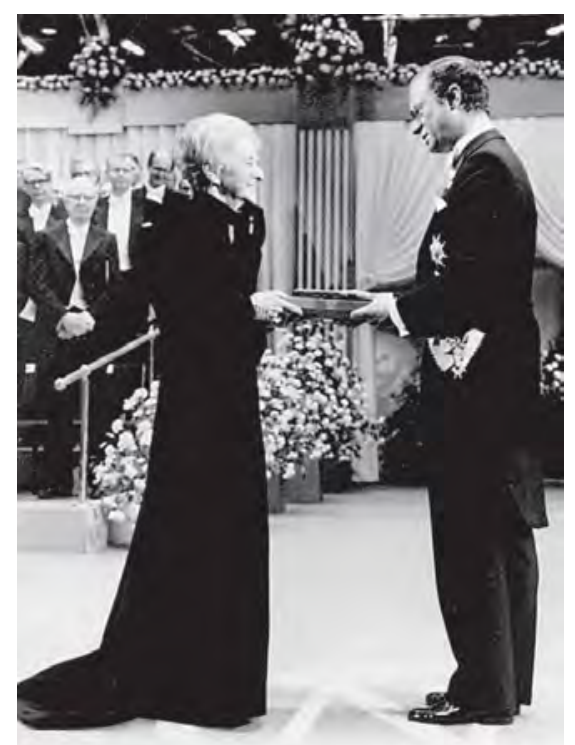

Rita Levi-Montalcini receives the Nobel Prize-1986 from the King of Sweden Carl XVI Gustaf ( ${ }^{\star}$ Levi-Montalcini. The nerve growth factor 35 years later. Science 1987; 237(4819):11541162. DOI:10.1126/science.3306916).

BDNF ( ${ }^{*}$ Sornelli F, Fiore M, Chaldakov GN, Aloe L. Adipose tissue-derived NGF and BDNF: results from experimental stress and diabetes. Gen Physiol Biophys 2009;28:179-183).

NT-3, NT-4/5, NT-6, NT-7

Trk (tyrosine receptor kinase) - pronounced "track“ ( ${ }^{\star}$ Yanev
S, Fiore M, Hinev

A, Ghenev PI, et al. From antitubulins to trackins. Biomed Rev 2016; 27:59-67.

TrkA (for NGF), TrkB (for BDNF and NT-3, TrkC (for NT-3) p75 ${ }^{\text {NTR }}$, p75 neurotrophin receptor - panneurotrophin receptor

To recap, many basic and clinical studies have been conducted on the association between adipokines, insulin sensitivity, cardiometabolic diseases (CMD) and longevity. The circulating levels of metabotrophic adipokines (metabotrophins) are reduced in individuals with obesity and related CMD ( ${ }^{\star}$ Matsuzawa Y. Adiponectin: a key player in obesity related disorders. Curr Pharm Des 2010;16(17):1896-901. DOI:10.2174/138161210791208893 * Samms RJ, Cheng CC, Kharitonenkov A, Gimeno RE, Adams AC. Overexpression of $\beta$-Klotho in adipose tissue sensitizes male mice to endogenous FGF21 and provides protection from diet-induced obesity. Endocrinology 2016;157(4):1467-1480. DOI: 10.1210/en.2015$1722{ }^{\star}$ Chaldakov GN, Fiore M, Stankulov IS, Manni L, et al. Neurotrophin presence in human coronary atherosclerosis and metabolic syndrome: a role for NGF and BDNF in cardiovascular disease? Prog Brain Res 2004; 146:279-289.*Manni L, Nikolova V, Vyagova D, Chaldakov GN, Aloe L. Reduced plasma levels of NGF and BDNF in patients with acute coronary syndromes. Int J Cardiol 2005; 102:169-171). Also see ${ }^{\star} \mathrm{Li}$ J, Kim SG, Blenis J. Rapamycin: one drug, many effects. Cell Metab 2014; 19(3):373-379. DOI:10.1016/j.cmet.2014.01.001. Rapamycin, a specific inhibitor of Mammalian target of rapamycin (mTOR), reduces AT accumulation and appetite in rats - possible therapeutic implications in human obesity require further studies.

\section{There are four major types of tissues}

Epitthelial tissue

Nervous tissue

Muscle tissue

- Smooth muscles

- Sriated muscles

- skeletal muscles

- cardiac muscles (cardiomyocytes)

Connective tissue

- Loose connective tissue

- Fibrous connective tissue

- Cartilage tissue

- Osseous (bone) tissue

- Adipose tissue

These tissues are schematically illustrated in Figure 7-9. 


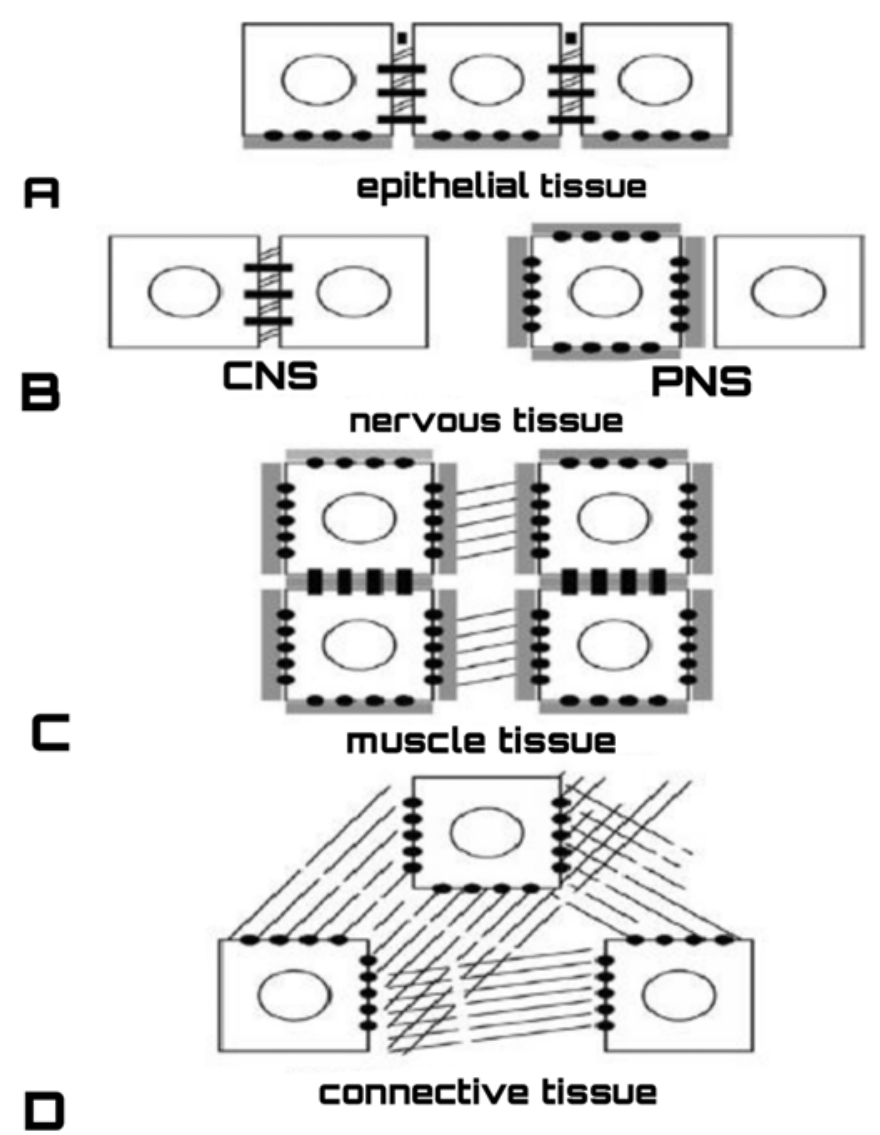

Figure 7. Scheme of the four major tissues (A - D). CNS, central nervous system, PNS, peripheral nervous system. From: Chaldakov GN. Cell Biology $2^{\text {nd }}$ edition. 2014.

\section{EPITHELIAL TISSUE}

BL

\section{LOOSE CONNECTIVE TISSUE}

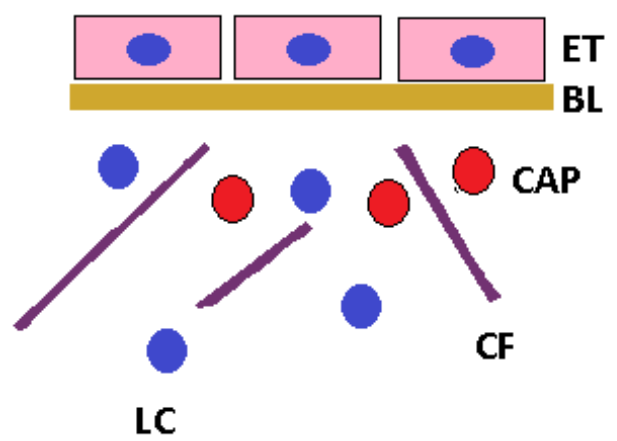

Figure 8. Scheme illustrating the relation between epitehelail tissue (ET) and loose connective tissue. BL, basal lamina, CAP, capillary, LC, lymphocyte, CF, collagen fiber. The author credits Nikifor Chaldakov for this drawing.

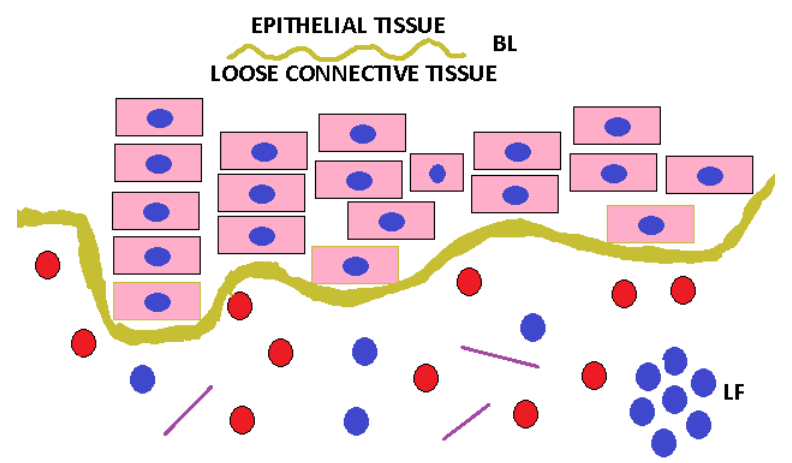

Figure 9. Scheme illustrating the relation between epitehelail tissue and loose connective tissue. BL, basal lamina, LF, lymph follicle. A drawing by Nikifor Chaldakov.

\section{There are two major types of adipose tissue}

Adipose tissue is very plastic tissue, being constantly remodeled along with weight gain and weight loss. It is a dynamic cellular and extracellular matrix assembly composed of adipocytes, fibroblasts, immune cells and matrix components, also rich in sympathetic nerve fibers, blood vessels, and stem cells.

White adipose tissue (WAT) and brown adipose tissue (BAT) are morphological and functional expressions of a dynamic system, consisting of adipocytes and non-adipocytes (so-called stromal vascular fraction consisted of fibroblasts, vascular cells, nerve cells, and immune-inflamamatory cells - mast cells and macrophages). Adipose tissue also contains adipose-derived stem cells (ADSC) that have the ability to differentiate into several lineages including neuronal cells and striated muscles. Noteworthy, AT is also located in cavernous sinus/parasellar region of the brain ${ }^{*}$ Weninger WJ, Prokop $\mathrm{M}$. In vivo 3D analysis of the adipose tissue in the orbital apex and the compartments of the parasellar region. Clin Anat 2004; 17:112-117); this needs further investigations.

These tissues are illustrated in Figure 10-13.

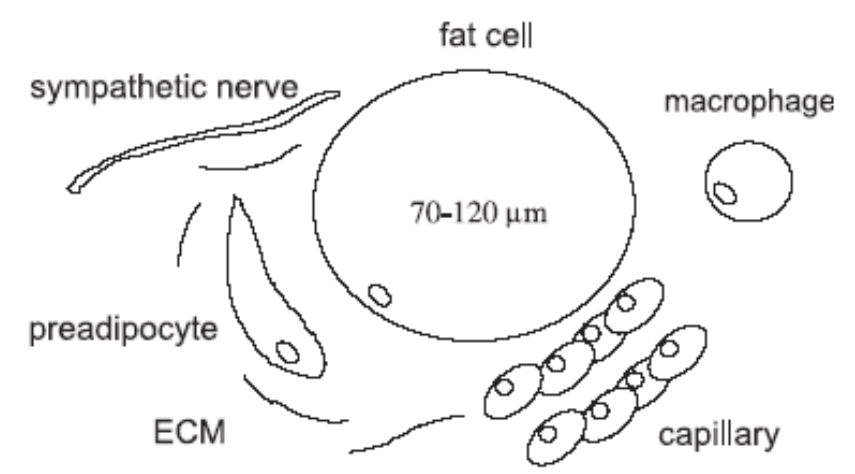

Figure 10. Main cellular components of human adipose tissue. ECM, extracellular matrix. From: Hauner H. Physiology \& Behavior, 2004. 
Figure 11. Light microscopical view of white adipose tissue stained with hematoxiline and eosin. A, adipocyte; B, blood vessel (capillary); arrows, nucleus. From: Gray's Anatomy, 40th edition. 2008.
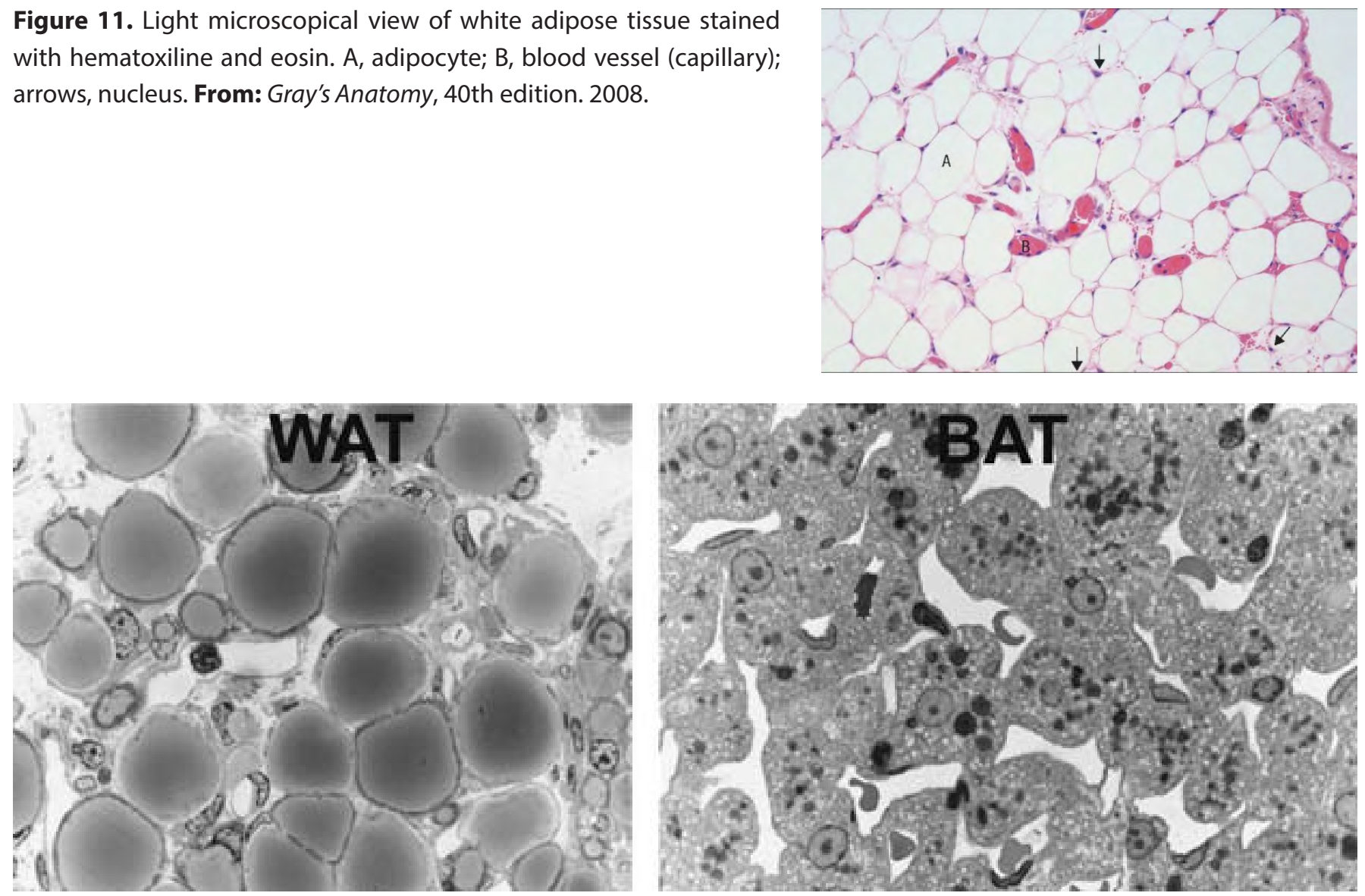

Figure 12. Light microscopy of murine white (left) and brown (right) adipose tissue. White adipocytes are roundish with unilocular lipid droplets. Brown adipocytes are polyhedral with multilocular lipid droplets. From: Cinti S, Vettor R. The adipose organ. In: Adipose Tissue and Infammation. Awad AB, Bradford PG, editors. 2010. Taylor and Francis Group, pp 1-21.
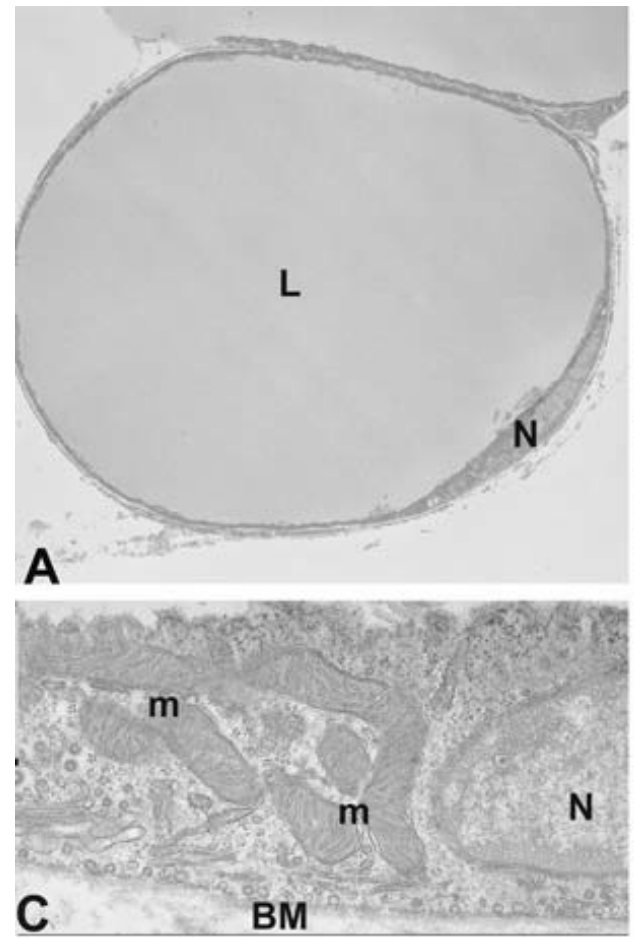
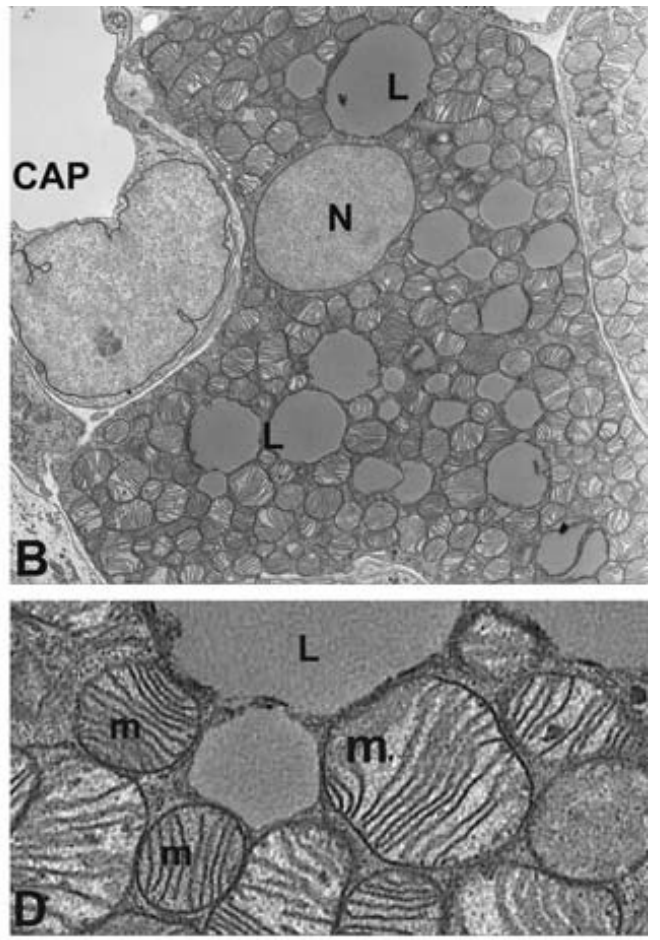

Figure 13. Transmission electron microscopy. A, C. Mouse white adipose tissue - adipocytes with one big lipid droplet (unilocular lipid droplet shown in A). L, lipid, N, nucleus. $\mathrm{m}$, mitochondria, $B M$, basal membrane (basal lamina). B, D. Mouse interscapular brown adipose tissue - adipocytes with numerous small lipid droplets (L) (multilocular lipid droplets), and many mitochondria $(\mathrm{m})$ shown in D. CAP, capillary lumen. From: Cinti S, Vettor R. The adipose organ. In: Adipose Tissue and Infammation. Awad $A B$, Bradford PG, editors. Taylor and Francis Group. 2010; pp 1-21. 
At birth, the average-size infant has approximately 5 billion adipocytes

(fat cells, lipocytes), whereas - approx. 80 billion in adult. Adding to them billions of stromal vascular cells, makes the whole body AT one of the largest human organs.

\section{White adipose tissue}

Partitioned into a few large depots (visceleral and subcutaneous) and many samall depots associated with the hearth, blood vessels, lymph nodes, bone marrow, pancreas and other internal organs (Fig.14).

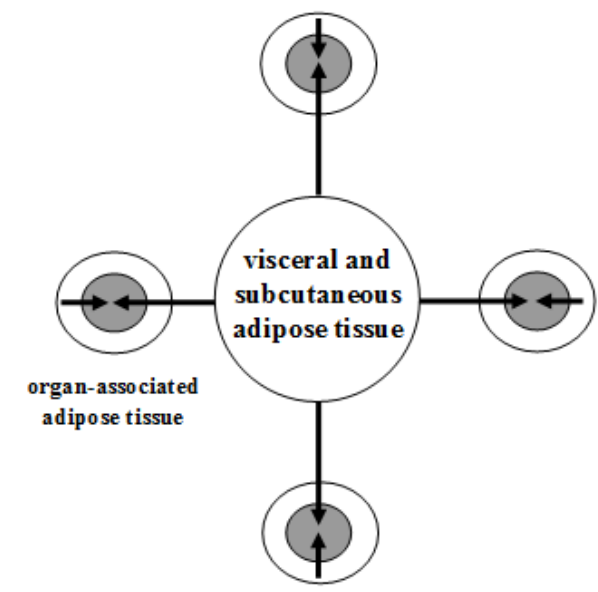

Figure 14. The topography of white adipose tissue. From: Chaldakov GN, Stankulov IS, Hristova M, Ghenev PI. Adipobiology of disease: adipokines and adipokine-targeted pharmacology. Curr Pharm Des 2003; 9:1023-1031.

\section{Brown adipose tissue}

BAT can be visualized using ${ }^{18} \mathrm{~F}$-fluorodeoxyglucose (FDG), an intravenously administered radioactive glucose analog taken up but not metabolized (by neoplasms and used to delineate metastatic cancers) viewed with positron emission tomography (PET) scans, also localized in BAT by concomitant computed tomography (CT) - PET-CT fusion scans.

\section{Visceral brown fat}

Perivascular: aorta, common carotid artery, brachiocephalic artery, paracardial mediastinal fat, epicardial coronary artery and cardiac veins, internal mammary artery, and intercostal artery and vein

Periviscus: heart, trachea and major bronchi at lung hilum, esophagus, greater omentum, and transverse mesocolon

Around solid organs: thoracic paravertebral, pancreas, kidney, adrenal, liver, and hilum of spleen

Subcutaneous brown fat

Between anterior neck muscles and supraclavicular fossa

Under the clavicles

In the axilla

Anterior abdominal wall

Inguinal fossa
From: Sacks H, Symonds ME. Anatomical locations of human brown adipose tissue. Functional relevance and implications in obesity and type 2 diabetes. Diabetes 2013; 62(6):17831790. DOI:10.2337/db12-1430

For BAT topography, also see Figure 15.
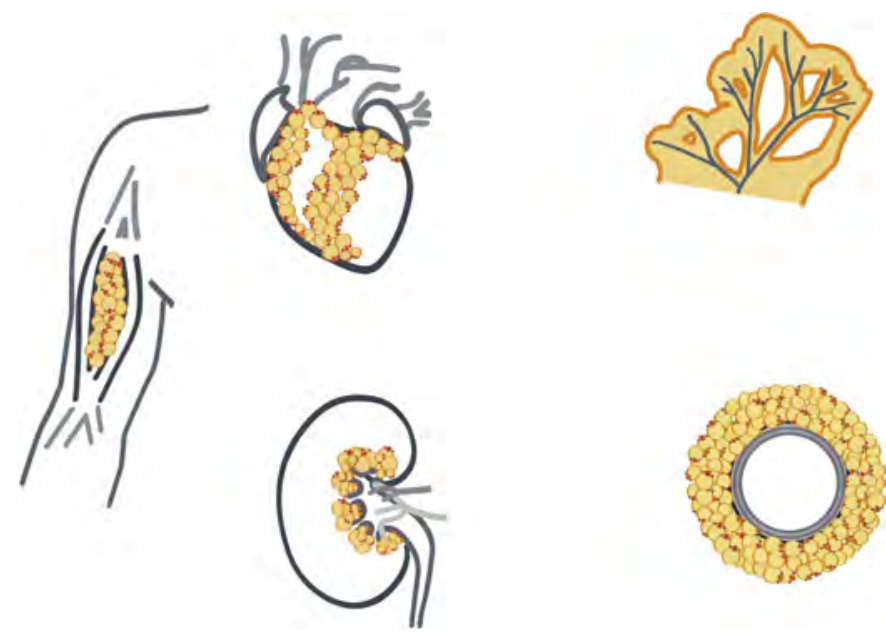

Figure 15. Regional perivascular adipose tissue (PVAT) depots are associated with specific vascular and metabolic complications. PVAT surrounding large arteries (aorta, mammary, radial, popliteal, tibial, femoral) modulates vascular biology via the secretion of local vasoactive adipokines. PVAT also surrounds veins, like the saphenous vein, where it reduces vasospasm and improves the patency of grafts in patients undergoing coronary artery bypass graft (CABG) surgery. A small PVAT depot is found within the kidney directly surrounding the renal artery and vein, the lymphatic vessels, and the proximal ureteral portion and has been associated with microalbuminuria. From: Gil-Ortega $M$, et al. Regional differences in perivascular adipose tissue impacting vascular homeostasis. Trends Endocrinol Metab 2015;1-9. DOI:10.1016/j.tem.2015.04.003

Adipokines, Adipocytokines, Adipokinome, and Secretome:

\section{In Nomine Veritas}

Indeed, many proof-of-concept studies have recently shifted the paridigm of AT from simple energy storage to the body's major endocrine and paracrine organ. Accordingly, multiple proteins synthesized, stored, and released by adipose cells have been collectively designated adipokines or adipocytokines. While at adipobiological level both names clearly articulate the secretory nature of adipose tissue cells, the name (nomina) "adipokines" carries a more accurate message of truth (veritas) than the name "adipocytokines" ("adipocyto-kines" or "adipocytokines"), because the term "adipokines", as introduced by us in 2000 , embodies the proteins secreted by both adipocytes 
and non-adipocyte cell types of AT as well as both the cytokine and non-cytokine proteins (Table 4). At functional levels, adipokines control multiple biological processes beyond lipid and carbohydrate metabolism. Recently, Trayhurn and Wood have conceptualized the secretory proteome of AT as adipokinome, whereas the whole spectrum of AT secretory molecules was designated secretome, the latter embodying both proteins (adipokines) and non-proteins such as steroid hormones, prostaglandins, and fatty acids ( ${ }^{*}$ Trayhurn P, Wood IS. Adipokines: inflammation and the pleiotropic role of white adipose tissue. Br J Nutr 2004;92:347. DOI:10.1079/bjn20041213).

Table 4. A selected list of adipokines

\section{- Adipocyte-secreted adipokines \\ Metallothionein-I, -II, Haptoglobin \\ Adipsin, Leptin, Adiponectin, Visfatin, Apelin, Acylation-stimulating protein}

\section{-Stromal vascular cells-secreted adipokines| Cytokines}

Interleukin-1 (IL-1), IL-1 receptor antagonist, IL-6, IL-10, IL-18, IL-32

Tumor necrosis factor-a, Leukemia inhibitory factor

Macrophage migration inhibitory factor, Macrophage inflammatory proteins

\section{Chemokines}

MCP-1 (CCL2), IL-8 (CXCL8), Eotaxin (CCL11), RANTES (CCL5), IP-10,

SDF-1 (CXCL12)

\section{Growth factors}

NGF, BDNF, FGF, TGF- $\beta$, CNTF, MCSF, BMP-2, HB-EGF, IGF

\section{Angiogenic factors}

Vascular endothelial growth factor, Hepatocyte growth factor Angiogenin, Angipoietin-2, Angiopoietin-like protein 4, Fastinginduced adipose factor, Fibrinogen-angiopoietin-related protein, Pigment epithelium-derived factor

\section{Renin-angiotensin system}

Renin, Angiotensinogen, Angiotensin I, Il, Aldosterone, Chymase

\section{Acute phase reactants}

Serum amyloid A, Lipocalin, Ceruloplasmin, PTX-3, CRP, Hypoxia inducible factor-1.

\section{Hemostatic factors}

Plasmonogen activator inhibitor type 1, Tissue factor

Enzymes

Lipoprotein lipase, Adipsin, Matrix metalloproteinases, Tryptase Extracellular matrix proteins

Collagen type I, III, VI, Fibronectin, Nidogen (entactin)

Others

FIZZ-1, Resistin (FIZZ-3), Omentin, Prolactin, Calcitonin, Somatostatin, agouti protein, Prohibitin, SPARC (Osteonectin), Tissue Inhibitors of Matrix Metalloproteinases, Cystatin C, Colligin-1, Vaspin, Adrenomedullin, Calcitinin Gene-Related Protein, Urocortin, Stresscopin, Retinol-binding protein-4, Hypoxia-inducible factor1a, Adhesion-regulating molecule-1, Calvasculin, Gelsolin,
Hippocampal cholinergic neurostimulating peptide, Semaphorin, Neutrophil gelatinase-associated lipocalin, Cholesteryl ester transfer protein, Zinc-alpha2-glycoprotein, also named Lipidmobilizing factor, Cathepsins C, D, S

Abbreviations: MCP-1 (CCL2), Monocyte Chemoattractant Protein-1 (Cysteine-Cysteine modif chemokine Ligand 2); RANTES, Regulated on Activated Normal T-cell Expressed and Secreted; IP-10; Interferon- $\gamma$-inducible Protein-10; SDF-1, Stromal cell-Derived Factor-1; FGF, Fibroblast Growth Factor; TGF- $\beta$, Transforming Growth Factor-beta; CNTF, Ciliary Neurotrophic Factor; MCSF, Macrophage Colony-Stimulating Factor; BMP-2, Bone Morphogenetic Protein-2; HB-EGF, Heparin-Binding EGF-like Growth Factor; IGF, Insulin-like Growth factor; PTX3, Pentraxin family member closely related to C-Reactive Protein (CRP); FIZZ, Found in Inflammatory Zone; SPARC, Secretory Protein, Acidic and Rich in Cysteine.

From: Töre F, Tonchev AB, Fiore M, Tunçel N, Atanassova P, Aloe L, et al.

From adipose tissue protein secretion to adipopharmacology of disease. Immun Endoc Metab Agents Med Chem 2007; 7:149-155. Also see * Renes J, Rosenow A, Mariman E. Novel adipocyte features discovered by adipoproteomics. Adipobiology 2009; 1:7-18.

\section{The intracellular secretory pathway of adipokines}

According to George Palade's classical concept and Gunter Blobel's signal theory, the protein secretory pathway constitutes of several intracellular steps, including synthesis, translocation, targeting, sorting, storage (in case of regulated versus constitutive secertion), and, finally, exocytosis (Table 5, Fig. 16). Generally, the secretory proteins are four major types: lysosomal, plasmalemmal, recycled, and exported.

About $30 \%$ of genes in WAT cells (adipocytes, stromal vascular cells, and associated immune cells) encode for adipokines. The adipokines are exported - endocrine and paracrine - proteins, whilst glucose transporters (GLUT) are recycled membrane proteins. Today, our knowledge of adipokine's intracellular secretory pathways remains limited, despite that the number of reported adipokines approaches five hundred, and their impact on the pathogenesis of various diseases is increasingly recognized.

Table 5. The Palade's protein secretory pathway

- Synthesis Ribosomes, RER

- Post-translational modification Golgi complex

- Sorting Günter Blobel's signaling amino acid sequence

- Storage Golgi complex, Secretory vacuoles

- Transport MT*, Kinesin, COP I, COP II, AF*, Myosin II

- Exocytosis Plasmalemma via Porosomes

*MT, microtubules; AF, actin filaments 


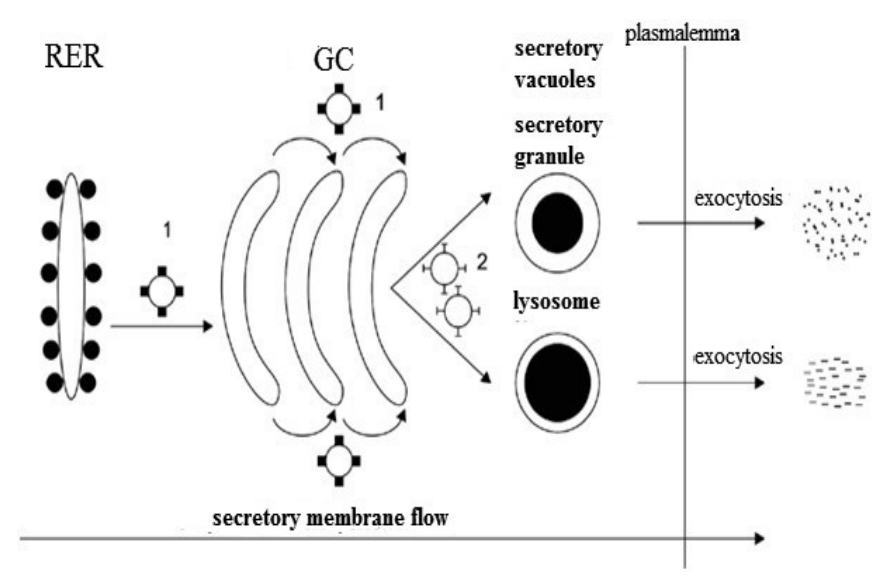

Figure 16. Scheme illustrating protein secretory pathway (secretory membrane flow), an example of fission-fusion biomorphogenic principle. RER, rough endoplasmic reticulum, GC, Golgi complex (briefly, Golgi), 1, COP (COated Protein) vesicle, 2, clathrin-coated vesicles. From: Chaldakov GN. Biomorphogenic principles of cell-matrix biology: A plectics insight. Biomed Rev 2019; 30:143-148.

Altogether, the vast majority of extracellular proteins are exported by the classical, RER-Golgi-dependent secretory pathway. Other proteins such as cytokines and matrix proteins (procollagen, proelastin, fibrilin, laminin, etc) use the unconventional protein secretion, also known as non-classical protein secretion or RER/Golgi-independent protein secretion. Two examples of the latter also are exosomes and ectosomes (see Fig. 17) - they carry important bioactive molecules (micro RNAs, DNA, Ig, etc) to communicate - via endo- and paracrine way - with other cells. For adipose-derived ectosomes (microparticles) and exosomes, see *Müller G, Schneider M, Biemer-Daub G, Wied S. Microvesicles released from rat adipocytes and harboring glycosylphosphatidylinositol-anchored proteins transfer RNA stimulating lipid synthesis. Cell Signal 2011;23(7):1207-1223. DOI:10.1016/j.cellsig.2011.03.013 * Zhang B, Yang Y, Xiang L, Zhao Z, Ye R. Adipose-derived exosomes: A novel adipokine in obesity-associated diabetes. J Cell Physiol. 2019; 234(10):16692-16702. DOI:10.1002/ jcp.28354.

Protein secretion is one of the basic cellular functions consisted of the following main processes: synthesis, storage, and exocytosis. In the proper sense of cell biological language, it is not correct to consider "secrete" as discharge or release - the latter are the final step of cell protein secretion - the exocytosis.

\section{USE IT OR LOSE IT}

Joseph T. Coyle, M.D. N EnglJ Med 2003; 348: 2489-2490.

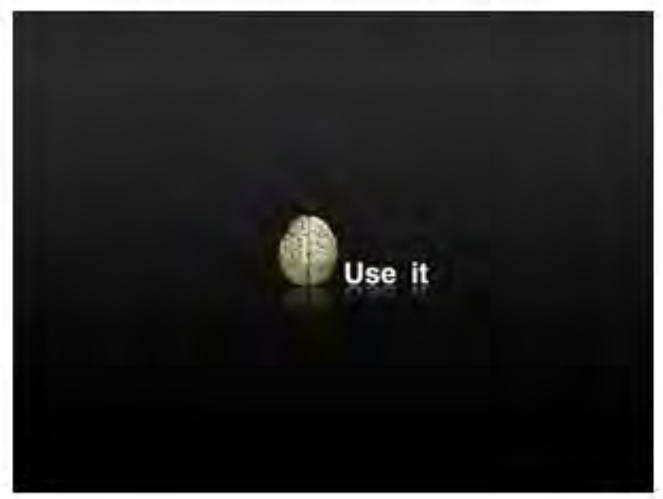

\section{Intermezzo-1}

Giorgio Amendola and Giorgio Napolitano were frequently seen together in the Italy of the 1960s, and were jokingly called by their friends "Giorgio "o chiatto" (Giorgio the fat) and "Giorgio "o sicco" (Giorgio the slim). Arguably, his "o sicco" status is why Giorgio Napolitano, at 94 years of age now, is still in a good body-and-mind health, and retaired after being two mandates President of Italy, also Italian representative in EU. If you buy this one-over-many argument (from Plato's Theory of Form), the power of "o sicco" AT is not to be underestimated. At least in Italy.

\section{The prototypic adipokine LEPTIN: The big fat bang}

As a doctor, you're trained to absorb the facts you're given and accept them.

Science is almost the opposite. It's a frontier of discovery that's always

moving. And I decided I wanted to do research.

Jeffrey Friedman

The discovery of leptin by the research group of Jeffrey Friedman published on $1^{\text {st }}$ December 1994 marked the paradigm shift in (white) adipocytes: from merely fat storage cells to secretory, endocrine and paracrine cells. ( ${ }^{*}$ Zhang Y, Proenca R, Maffei M, Barone M, Leopold L, Friedman JM. Nature 1994: 372:425-432).

In this stream, the pioneering contribution of Douglas Coleman (1931-2014) has to be acknowledged. His work established the first clues to a genetic component in obesity. In the 1970s, Coleman conducted a series of experiments that led him to propose the existence of a satiety factor that would account for obesity and type 2 diabetes among certain laboratory mice.

Leptin's CV is shown in Table 6. 
Table 6. Curriculum vitae of leptin

Name: Leptin, 16 kD, 167 amino acids

Gene: Obese (ob, Lep), Chromosome 7q31.3

Receptors: Ob-R (LEP-R, CD295), db gene splicing products

LEP- $R_{L}$ (LEP-Rb, long form of the leptin receptor, containing a 302 amino acid cytoplasmic domain)

LEP-R $_{\mathrm{s}}$ (LEP-Ra, c, d, e, f, OB-R short form, containing a 34-amino acid cytoplasmic domain)

Low-density lipoprotein-related protein 2 (LRP2), also known as Megalin (gp330*

Born officially: 1 December 1994 in Nature 1994; 372: 425-432.

Official birth place: Laboratory of Molecular Genetics, The Rockefeller University

York Avenue, between $63^{\text {rd }}$ and $68^{\text {th }}$ Streets, the Upper East Side of Manhattan, New York City, NY, USA

Natural birth place: white adipocytes

Other birth places: gastric epithelial cells, cardiomyocytes, lung perialveolar fibroblasts, ovaries, bone marrow, placenta, lymphocytes, mast cells, macrophages, liver perisinusoidal lipid storage cells (Ito cells, hepatic stellate cells)

Functions: food intake, energy expenditure, cell growth, reproduction, immunity, hemostasis, angiogenesis, fibrogenesis, osteogenesis, neuroprotection, memory, mood

* *Hama H, Saito A, Takeda T, et al. Evidence indicating that renal tubular metabolism of leptin is mediated by megalin but not by the leptin receptors. Endocrinology 2004; 145(8):3935-3940. DOI:10.1210/en.2004-0074*Dietrich MO, Spuch C, Antequera D, et al. Megalin mediates the transport of leptin across the blood-CSF barrier. Neurobiol Aging 2008; 29(6):902-912. DOI:10.1016/j.neurobiolaging.2007.01.008

Leptin resembles interleukin-6 (IL-6) and both are members of the cytokine superfamily of proteins. Leptin functions as an afferent signal in a negative feedback loop that regulates food intake and energy homeostasis to maintain control of adipose tissue mass. From the adipocytes leptin is exported into the blood circulation, enters the brain and stimulates anorexogenic and inhibits orexogenic neurons (Table 7-9), arcuate, paraventricular, dorsomedial and ventromedial nucleus and hypothalamus being the brain leptin sensitive hub. The net effect of these actions is satiety, stop eating. When mice leptin gene is deleted (knockout) (ob/ob mice) or the gene for leptin receptor is deleted $(\boldsymbol{d} \boldsymbol{b} / \boldsymbol{d} \boldsymbol{b}$ mice), the mice eat without filling of satiety, thus becoming obese and diabetic respectively $\left({ }^{\star}\right.$ Friedman JM. Leptin at $14 \mathrm{yr}$ of age: an ongoing story. Am J Clin Nutr 2009; 89: 973S-979S).
Table 7. Adipose-brain talk: examples of neuromediators in leptin signaling

\author{
Anorexigenic pathway (up-regulated) \\ Proopiomelanocortins \\ Melanocortin 4 \\ a-melanocyte stimulating hormone \\ Brain-derived neurotrophic factor \\ Orexigenic pathway (down-regulated) \\ Neuropeptide tyrosine (NPY) \\ Agouti-related protein \\ Endocannabinoids
}

Table 8. List of cell fuctions under control of leptin

Appetite suppressor (anorexogenic adipokine)

Energy homeostasis (energy expenditure adipokine)

Inflammation, Immunity

Increase collagen production

Increase surfactant production by lung alveolar type II pneumocytes

Male and female fertility

Promotion of angiogenesis

Stimulation of bone growth

Stimulation of collagen fibrogenesis and inhibition of MMP-1*

Improve memory and mood**

* Matrix metalloproteinase-1 also known as collagenase. Briefly, leptin is a potent fibrogenic factor invoved in the pathogenesis of fibroprilifearaive diseases such as atherosclerosis (*Beltowski J. Leptin and atherosclerosis. Atherosclerosis 2006;189(1):47-60. DOI:10.1016/j.atherosclerosis.2006.03.003) and liver cirrhosis (see Table 6 for the fibrogenic hepatic stellate cells) (*Saxena NK, Ikeda K, Rockey DC, et al. Leptin in hepatic fibrosis: evidence for increased collagen production in stellate cells and lean littermates of ob/ob mice. Hepatology 2002; 35:762-771. *Gertler A, Elinav E. Novel superactive leptin antagonists and their potential therapeutic applications. Curr Pharm Des 2013; 20(4):659-665.

DOI:10.2174/13816128113199990014).

**Leptin's cognitive effects may be relevant to the pathobiology and therapy of Alzheimer's disease and depression ( ${ }^{*}$ Greco SJ, Bryan KJ, Sarkar S, Zhu X, Smith MA, Ashford JW, et al. Leptin reduces pathology and improves memory in a transgenic mouse model of Alzheimer's disease. J Alzheimers Dis 2010; 19:1155-1167 *Kiliaan AJ, Arnoldussen IA, Gustafson DR. Adipokines: a link between obesity and dementia? Lancet Neurol 2014;13:913-923. DOI:10.1016/S1474-4422(14)70085-7). 
Table 9. A selected list of leptin-related diseases

Obesity, Atherosclerosis, Hypertension, Metabolic syndrome, Type 2 diabetes

Anorexia nervosa, Bulimia nervosa, Alzheimer's disease, Depression, Schizophrenia

Liver cirrhosis, Nonalcoholic fatty liver disease

Amenorrhea, Osteoporosis, Rheumatoid arthritis

Cancers, Cancer-related cachexia

Bronchial asthma, Chronic obstructive pulmonary disease

Obstructive sleep apnea, Polycystic ovary syndrome

Lipoatrophic diabetes mellitus*

* Lipoatrophic diabetes is characterized by severe insulin resistance, hypoleptinemia, and hyperphagia, and having no WAT. Transplantation of WAT from healthy mice into these lipoatrophic mice resulted in a reversal to physiological phenotype. It appears that too much WAT is bad and so is not enough WAT. The punch line here is that "a little fat is good."

\section{The joy of discovery}

Dear Dr Chaldakov and Colleagues,

Thanks to you for what I believe to be the only birthday party celebrating the anniversary of the cloning of the $o b$ gene. I had forgotten entirely that this milestone was about to pass and am grateful to you all for bringing this to my attention. I will now have to organize a party here as well. It is hard to believe so much time has passed. I hope you have a productive and illuminating meeting and wish you the joy of discovery.

\section{Regards,}

Jeffrey Friedman

\section{Intermezzo-2}

Professor, Rockefeller University

The thrifty-genotype hypothesis invokes an evolutionary survival advantage for organisms capable of building energy stores quickly and efficiently, that is, to accumulate adipose tissue. However, it is not infrequent that too much of a good thing amounts to a bad one, and AT is no exception to this rule. Excess of intraabdominal (visceral) AT mass is associated witht CMD, a main threat to modern affluent societies.

\section{Obesity: an adipose accumulation associated with many comorbidities}

At its core, obesity may be classified as accumulation and inflammation of WAT and dysfunction of BAT. According to the World Health Organization (WHO) these diseases account for most NCD deaths - 17.7 million people annually, followed by cancers (8.8 million) and respiratory diseases (3.9 million). These diseases account for over $80 \%$ of all premature NCD deaths. WHO's key facts updated in October 2017 demonstrated that (i) worldwide obesity has nearly tripled since 1975, (ii) in 2016, more than 1.9 billion adults were overweight of these over 650 million were obese, (iii) 41 million children under the age of 5 were overweight or obese in 2016, (iv) it is predicted that overweight and obese people may be 2.7 billion in 2025 .

\section{Obesity is a low-grade inflammatory disease}

Celsus's description (1st century AD) of inflammation includes: rubor et tumor cum calor et dolor. Inflammation is an essential biological response aiming at recovering from injury, wound healing being a paradigm of such a homeostatic phenomenon. However, what begins as a protective response, in excess becomes a damaging process, hence the inflammation is increasingly recognized as the underlying basis of a significant number of diseases. Recent genomic studies in human WAT revealed that a large number of inflammatory molecules was upregulated in obese compared to lean subjects ( ${ }^{*}$ Unamuno X, Gómez-Ambrosi J, Ramírez B, et al. NLRP3 inflammasome blockade reduces adipose tissue inflammation and extracellular matrix remodeling. Cell Mol Immunol 2019; DOI:10.1038/ s41423-019-0296-z).

Inflammasomes are macromolecular complexes consisted of nucleotide-binding oligomerization domain (NOD)-like receptors (NLR) - nucleotide-binding domain and leucine-rich repeat protein 3 (NLRP3), and protelytic enzymes (capsase-1, -5). These complexes convert precursors of the proinflammatory cytokines IL-1 $\beta$, IL-18 and IL-33 into bioactive forms ( ${ }^{\star}$ Gadola SD. Interleukin-1 cytokines, inflammasomes, NODsignalosomes and autoinflammation. Z Rheumatol 2009; 68:712-719 *Mariathasan S, Monack DM. Inflammasome adaptors and sensors: intracellular regulators of infection and inflammation. Nat Rev Immunol 2007; 7(1):31-40).

\section{Does the adipose tissue tell our brain what to do?}

Today, AT is "getting nervous" (*Fliers E, Kreier F, Voshol PJ, et al. White adipose tissue: getting nervous. J Neuroendocrinol 2003; 15: 1005-1010). Metaphorically, this talented tissue is increasing dramatically its intelligence quotient (IQ) $\left({ }^{\star}\right.$ Chaldakov GN, Fiore $\mathrm{M}$, Tonchev AB, et al. Tissue with high IQ: adipose-derived stem cells in neural regeneration. Neural Regen Res 2009; 4:1116-1120). It is known that the gut is considered a second brain, AT may likely function as a third brain $\left({ }^{*}\right.$ Chaldakov GN, Fiore M, Tonchev AB, et al. The adipose tissue as a third brain. Obes Metab 2009; 5:94-96).

In 1999, Albee Messing has published Editorial entitled "Nestin in the Liver - Lessons from the brain" ( ${ }^{\star}$ Hepatology 1999; 29: 602-603). He wrote therein: "Most neuroscientists manage to get through each day without thinking of the liver even once... but I think that is about to change." 
This may also be the case for AT, herein designated as neuroadipology or neuroadipocrinology $\left({ }^{*}\right.$ Chaldakov GN, Fiore M, Tonchev AB, Aloe L. Neuroadipology: a novel component of neuroendocrinology. Cell Biol Int 2010; 34:1051-1053).

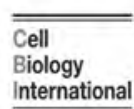

$$
\text { Review Article }
$$

Neuroadipology: a novel component of neuroendocrinology

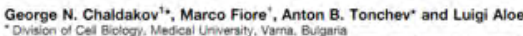

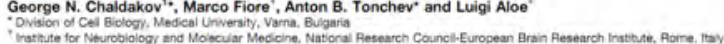

A selected lsit of neural and neuroendocrine biomarkers expressed in AT is presented in Table 10.

Table 10. Neural and neuroendocrine markers in adipose tissue

Semaphorin (Sema3A), Neuropilin-1, Pantophysin

Neuronal nuclear antigen, Nestin, Neuron-specific enolase

Glial fibrillary acidic protein, Vimentin, Stathmin-like 2

NF70, S100, Musashi-1 genes, Beta3 tubulin

Acetylcholinesterase and choline acetyltransferase

Amyloid precursor protein, Abeta peptides (possiblly related to Alzheimer's disease)

\section{Adipobiology: The Renaissance of a tissue marked by several paradigm shifts}

The new paradigm should always be better, not just different.

Thomas Kuhn

One of biggest recent achievements in studying CVD (atherosclerosis and hypertension) and metabolic diseases (obesity, T2DM, metabolic syndrome, and Alzheimer's disease which is recently viewed as type 3 diabetes) is associated with the "rediscovery" (second Eureka) of a neglected tissue, the adipose tissue.

In 1962 Thomas S. Kuhn published his book The Structure of Scientific Revolutions. University of Chicago Press, Chicago, USA. Its publication was a landmark event in history and philosophy of scientific knowledge (epistemology). Kuhn challenged the then prevailing view of "normal science" which was viewed as "development-by-accumulation" of accepted facts and concepts leading - most oftenly - to epistemological paraly$s i s$, we dubbed it neophobia. Kuhn argued for a model in which a period of such conceptual continuity in normal science were interrupted by a period of revolutionary science leading to a new paradigm, an event he designated paradigm shift.
At epistemological level, the AT has undergone four major paradigm shifts in the last 25 years. This rise it above the horizon to take center stage in so many diseases that it leaves most scientists and medical doctors astonished.

\section{The first paradigm shift in adipobiology}

While considered as passive storage-release of lipids by most cell biologists and pathologists for a long period of time, AT, especially WAT, emerges recently as one of the biggest multifunctional (multicrine) human tissues (Table 11).

Table 11. Examples of paradigm shifts in adipobiology

\section{FROM}

The adipose tissue is a lipid storage-release organ involved in obesity

To

Adipose tissue is an endocrine, paracrine and autocrine organ Adipose tissue is a neuroendocrine organ Adipose tissue is a steroidogenic organ

Adipose tissue is an immune organ

Adipose tissue is a source of and target for in!ammatory mediators

Adipose tissue produces all components of rennin-angiotensin system

Adipose tissue is a storage-release site of xenobiotics and xenobiotic-metabolizing cytochrome P450 enzymes

By sending and receiving different types of protein and nonprotein signals, WAT communicates with many organs in the body (Fig. 17), thus contributing to its multifunctionality in health and disease. 


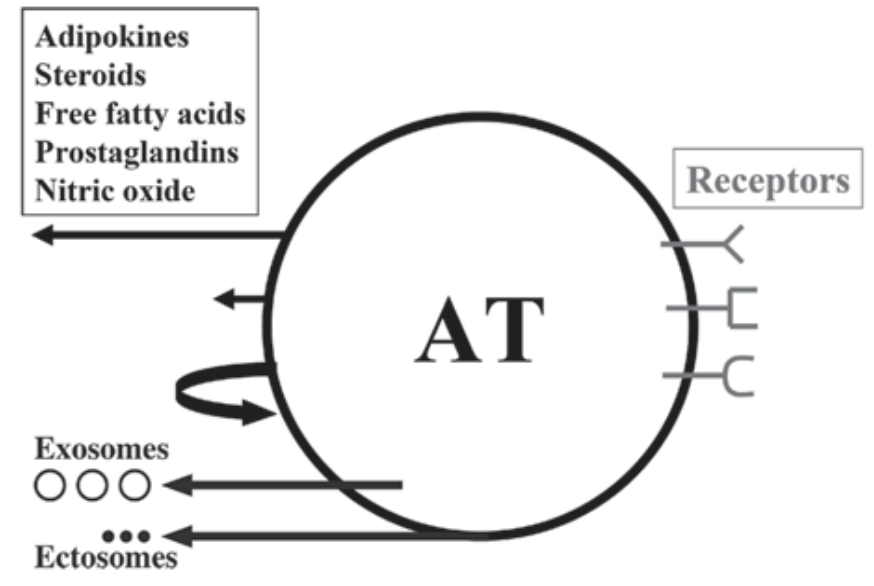

Figure 17. A drawing illustrating both secretory and receptor nature of adipose tissue (AT) cells (adipose cells). Listed in the box are several adipose-secreted signaling molecules, which may communicate via multiple pathways, such as endocrine (arrows 1, 4 and 5, from top to bottom), paracrine (arrow 2) and autocrine (arrow 3, curved). Also depicted are (i) adipose cell's receptors for various ligands (signaling molecules), and (ii) adipose-derived exosomes (released from multivesicular bodies - the latter not shown) and ectosomes (microparticles originated from plasmalemma). From: Chaldakov GN, Aloe L, Tonchev AB, Fiore M. Chapter 11. From Homo obesus to Homo diabesus:Neuroadipology insight. In: C. Nóbrega, R. Rodriguez-López, editors. Molecular Mechanisms Underpinning the Development of Obesity, 2014; pp 167-178. DOI 10.1007/978-3-319-12766-8_11

The second paradigm shift in adipobiology derived from the study of Jeffrey Bell and colleagues who have scanned nearly 800 people with magnetic resonance imaging (MRI) technique, aimed at obtaining map of WAT. The authors demonstrated that as many as $45 \%$ of women and nearly $60 \%$ of men scanned have normal scores of the body mass index (BMI, 20-25 kg/m²). These people are thin outside (TO), while actually have excessive levels of internal adipose tissue - they are fat inside (FI), hence TOFI phenotype of body adiposity (hidden, internal obesity). Noteworthy, TOFI phenotype was also found among people who are professional models. TOFI may thus be considered a specific, "invisible" expression of both Homo obesus and Homo diabesus (Fig. 18, Table 12, also see Table 13).

\section{Fight diabesity: stay TOTI !!}

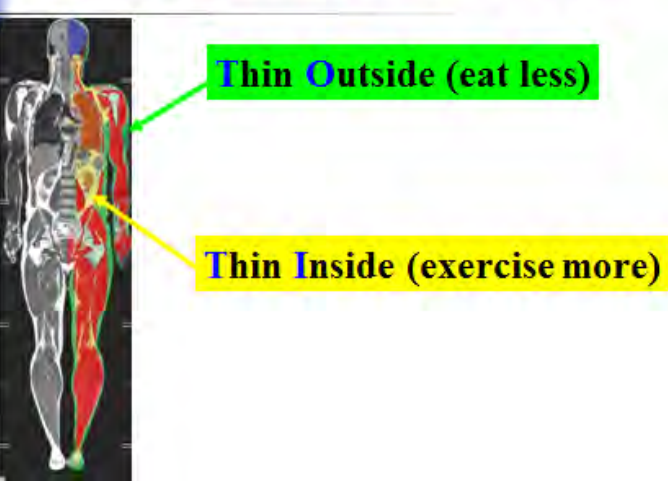

Figure 18. A map of white adipose tissue (WAT) obtained by magnetic resonance imaging (MRI) technique. TOTI stands for thin outside, thin inside, the salutogenic phenotype of WAT distribution in the human body. From Jimmy Bell's research group: *Thomas EL, Parkinson JR, Frost GS, et al. The missing risk: MRI and MRS phenotyping of abdominal adiposity and ectopic fat. Obesity (Silver Spring) 2012; 20(1):7687. DOI:10.1038/oby.2011.142. Also see ${ }^{*}$ Chaldakov GN. Obesity: an inside versus ouside view. Jimmy Bell and the Little Prince. A science-in-fiction dedicated to World Obesity Day. Scripta Scientifica Vox Studentium 2017;1 (1):13-17.

Table 12. Localization of human adipose tissue: variants +

$\mathrm{TOFI}^{* *}$ thin outside, fat inside

$\mathrm{TOTI}^{* * * * *}$ thin outside, thin inside

FOFI* fat outside, fat inside

FOTI $^{* * *}$ fat outside, thin inside

+ The number of stars means quality of health $(\mathrm{QoH})$ that can ensure good quality of life (QoL) - again, the main duty of the physicians, medical and dental doctors.

Table 13. Human weight and body mass index (BMI) values

\section{Weight BMI (kg/m2)}

Underweight $16-18$

Normal 18 - 25

Overweight 25 - 30

Average obese 30 - 35

Severe obese 35 - 40

Extremely (morbid) obese $>40$ 
The third paradigm shift features the increasing significance of BAT in health and disease. Recently, the knowledge about WAT and BAT were enriched with their relatives, namely brite (brown-in-white) and bruscle (brown-in-skeletal muscle) adipocytes. Hence, brown adipobiology is emerging as a new challenge in biomedicine $\left({ }^{*}\right.$ Frühbeck G, Becerril S, Sáinz $\mathrm{N}$, et al. BAT: a new target for human obesity? Trends Pharmacol Sci 2009;30:387-396. ${ }^{\star}$ Sacks H, Symonds ME. Anatomical locations of human brown adipose tissue functional relevance and implications in obesity and type 2 diabetes. Diabetes 2013; 62: 1783-1790. DOI: 10.2337/db12-1430).

\section{The fourth paradigm shift: Cognitive adipobiolgy}

As shown in Table 1, adipose cells secrete various neurotrophic factors. Likewise, a growing body of evidence demonstrated a link between obesity, T2DM, adipokines and the pathogenesis of Alzheimer's disease ( ${ }^{*}$ Naderali EK, Ratcliffe SH, Dale MC. Review: obesity and Alzheimer's disease: a link between body weight and cognitive function in old age. Am J Alzheimer's Dis Other Demen 2009; 24: 445-449. * Dar TA, Sheikh IA, Ganie SA, et al. Molecular linkages between diabetes and Alzheimer's disease: Current scenario and future prospects. CNS Neurol Disord Drug Targets 2014; 13:290-298. *Aloe L, Tonchev AB, Maucher A, Fiore M,. Zhelezov MD, et al. Adipobiology of the brain: From brain diabetes to adipose Alzheimer's disease. Adipobiology 2015; 7:37-42).

It was found an extraneuronal, including in AT, production of amyloid precursor protein (APP), one of the signature proteins in the process of alzheimerogenesis, $\left({ }^{*}\right.$ Puig KL, Combs
CK. Expression and function of APP and its metabolites outside the central nervous system. Exp Gerontol 2013; 48: 608611. DOI: 10.1016/j.exger.2012.07.009).

Adipose plasticity: there are five major types of adipose tissues

(i) White adipose tissue (WAT) - major human's secretory (endo- and paracrine) tissue

(ii) Brown adipose tissue (BAT) - thermogenic tissue, producing heat via activation of UCP-1 (uncoupling protein-1)

(iii) Brown-in-white (brite) adipose tissue, (iv) Beige adipose tissue (Fig. 19)

(v) Pink adipose tissue (PAT) - transdifferentiation of subcutaneous white adipocytes to alveolar epithelial milk-producing cells of the mammary gland during pregnancy and lactation ( ${ }^{*}$ Giordano A, Smorlesi A, Frontini A, Barbatelli G, Cinti S. White, brown and pink adipocytes: the extraordinary plasticity of the adipose organ. Eur J Endocrinol 2014; 170(5):R159-171. DOI:10.1530/EJE-13-0945).

Browning of WAT, also referred to as beiging, occurs when adipocytes within WAT develop features of brown adipocytes. Beige and brite) adipocytes have multilocular appearance (containing many lipid droplets and increase expression of uncoupling protein 1 (UCP1). In doing so, these normally energy-storing adipocytes become energy-releasing adipocytes $\left({ }^{*}\right.$ Rodríguez A, Becerril S, Ezquerro S, Méndez-Giménez L,Frühbeck G. Crosstalk between adipokines and myokines in fat browning. Acta Physiol (Oxf) 2017;219(2):362-381. DOI: 10.1111/apha.12686).

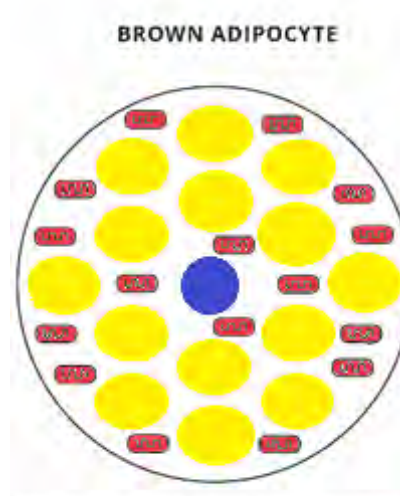

Densely packed small lipid droplets High density of mitochondria

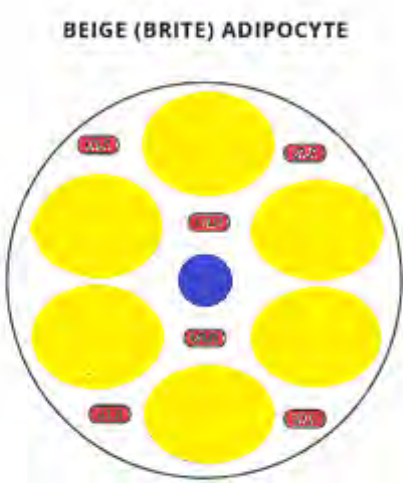

Moderately packed lipid droplets Moderate density of mitochondria
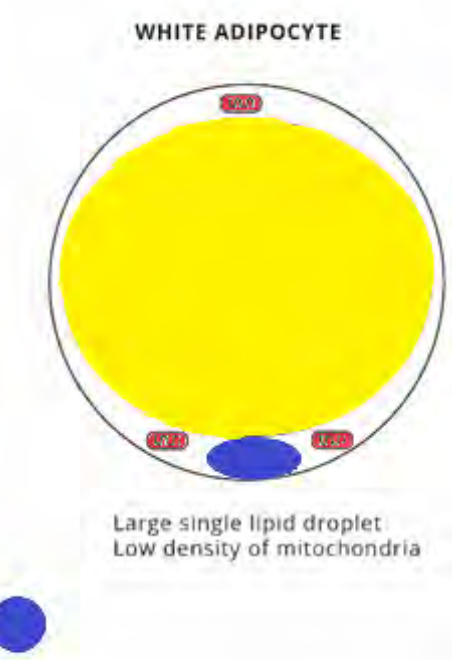

NUCLEUS
Figure 19. Schematic rendition of three different phenotypes of adipocytes. From: Jacob VD, Manoj KM. Are adipocytes and ROS villains, or are they protagonists in the drama of life? The murburn perspactive. Adipobiology 2019; 10:7-16. 


\section{Food for thought-1: cold, BAT, and obesity}

Cold exposure, a classical activator of BAT, protects animals against hypothermia and obesty $\left({ }^{*}\right.$ Valgas da Silva CP, Hernández-Saavedra D, White JD, Stanford KI. Cold and exercise: Therapeutic tools to activate brown adipose tissue and combat obesity. Biology 2019; DOI:10.3390/biology8010009). Biomolecules which transform white into brown and beige adipocytes are listed in Table 14 - these represent potential therapeutic targets for the therapy of obesity and its related diseases

\section{Table 14. Selected Isit of browning hormones}

Catecholamines, Thyroid hormones

Irisin, adipokine and myokine

BDNF, BMP-7, FGF-21

PGC-1a (peroxisome proliferator-activated receptor gamma coactivator 1) family of transcriptional coactivators

Peroxisome proliferator-activated receptor gamma (PPAR $\gamma$ )

PRDM16 (PR domain containing 16)

Early B-Cell Factor proteins (EBF1 and EBF2), transcription factors* Ang-(1-7), angiotensin 1-7**

* *Stine RR, Shapira SN, Lim HW, Ishibashi J, Harms M, Won KJ, Seale P. EBF2 promotes the recruitment of beige adipocytes in white adipose tissue. Mol Metab 2015; 5(1):57-65. DOI: 10.1016/j. molmet.2015.11.001)

** Ang-(1-7) is a heptapeptide vasodilator of the renin angiotensin system. An increased Ang-(1-7) blood level is associated with an anti-obesity effect most probably due to Ang-(1-7)'s browning action (*Vargas-Castillo A, Torres N, Tovar AR. Angioetensin 1-7 as an inducer of the browning capacity of white adipose tissue (abstract). Adipobiology 2019; 10:63).

In the SOA, angiotensin converting ezyme (ACE) converts Ang I to Ang II is the well known enzyme and its inhibitors are prescribed for the therapy of hypertension. Aangiotensin converting ezyme 2 (ACE2) further metabolize Ang II (vasoconstrictor) to Ang 1-7 (vasodilatator).

\section{Food for thought-2: ACE2 and SARS-CoV}

Aangiotensin converting ezyme 2 is a single-pass plasmalemmal protein, an enzyme expressed in many cell types, including in small intestine enterocytes and type II pneumocytes of lung alveoli. By proteolytic cleavage, its ectodomain can be sheded from plasmalemma (cell surface) and released into the blood circulation. The membrane-bound form of ACE2 serves as receptor for SARS-coronavirus (SARS-CoV) for its entry in the type II pneumocytes causing severe acute respiratory syndrome (SARS). The spike glycoprotein (S protein) on SARSCoV's surface mediates receptor-mediated membrane fusion followed by the cell entry of SARS-CoV. Therefore, blocking the ligation of CoV's S protein and ACE2 may have therapeutic potential for SARS $\left({ }^{*}\right.$ Gallagher TM, Buchmeier MJ. Coronavirus spike proteins in viral entry and pathogenesis. Virology 2001;279(2):371-374. DOI: 10.1006/viro.2000.0757 ${ }^{\star} \mathrm{Li}$ W, Moore MJ, Vasilieva N, Sui J, Wong SK, Berne MA, et al. Angiotensin-converting enzyme 2 is a functional receptor for the SARS coronavirus. Nature 2003;426: 450-454).

Type II pneumocytes are the most numerous cells in lung alveoli. These cells synthesize and store lamellar bodies which are exocytosed as pulmonary surfactant, a film of phospholipids that reduce alveolar surface tension. Without pulmonary surfactan, the alveoli collapse, and SARS may develop.

\section{Food for thought-3: to store or burn?}

- WAT is fat storing and adipokines secreting

- BAT is fat burning (thermogenic) organ (Fig. 17)

- Uncoupling protein-1 (UCP1), the signature protein of brown and beige adipocytes, resides in the inner mitochondrial membrane of these cells. When activated, UCP1 dissipates the proton gradient generated by the electron transport chain, which, in turn, drives high levels of substrate oxidation and results in the generation of heat. BAT's sympathetic nerves are critically involved in the regulating both the growth of BAT and its thermogenic activity. Brown adipocytes are innervated by sympathetic nerves, which upon cold exposure, release norepinephrine which in turn stumulates thermogenesis $\left({ }^{\star}\right.$ Kajimura S, Spiegelman BM, Seale P. Brown and beige fat: Physiological roles beyond heat generation. Cell Metab 2015; 22(4):546-559. DOI:10.1016/j.cmet.2015.09.007 ${ }^{\star}$ Liu X, et al. BAT transplantation reverses obesity in $\mathrm{Ob} / \mathrm{Ob}$ mice. Endocrinology 2015; 156:2461-2469. DOI: 10.1210/en.2014-1598).

\section{Other types of lipid-laden cells}

- Hepatic stellate cells (Ito cells, liver perisinusoidal fatstoring cells) - pericytes (cell component of capillaries), which may phenotypically modulate into myofibroblasts, a fibrogenic cell type, involved in the pathogenesis of liver cirrhosis.

- Arterial foam cells (monocyte-derived macrophages) involved in the formation of atherosclerotic plaques.

- Pulmonary alveolar lipofibroblasts - involved in alveolar surfactant production, its deficit related to pulmonary diseases ( ${ }^{*}$ Torday J, Rehan VK. Exp Cell Res 2016;340(2):215219. DOI:10.1016/j.yexcr.2015.12.004).

Some basic features of adipose tissue are shown in Figure 20, 21. 
Lean adipose tissue

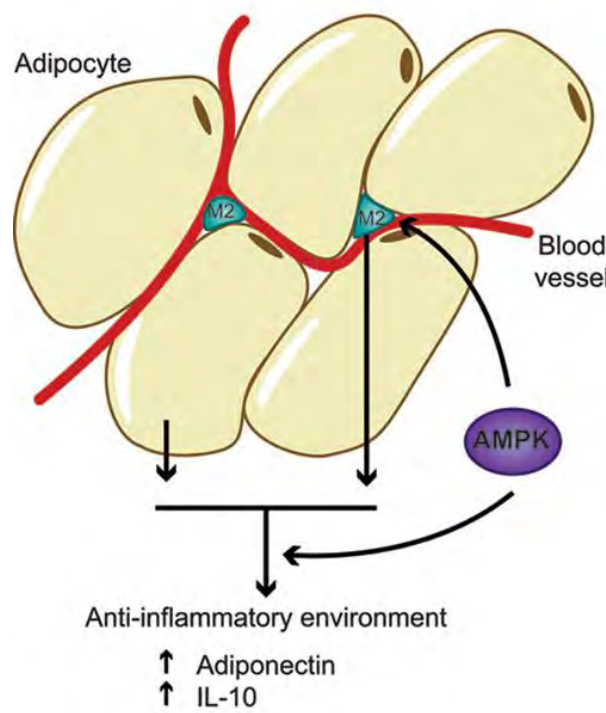

Obese dysfunctional adipose tissue

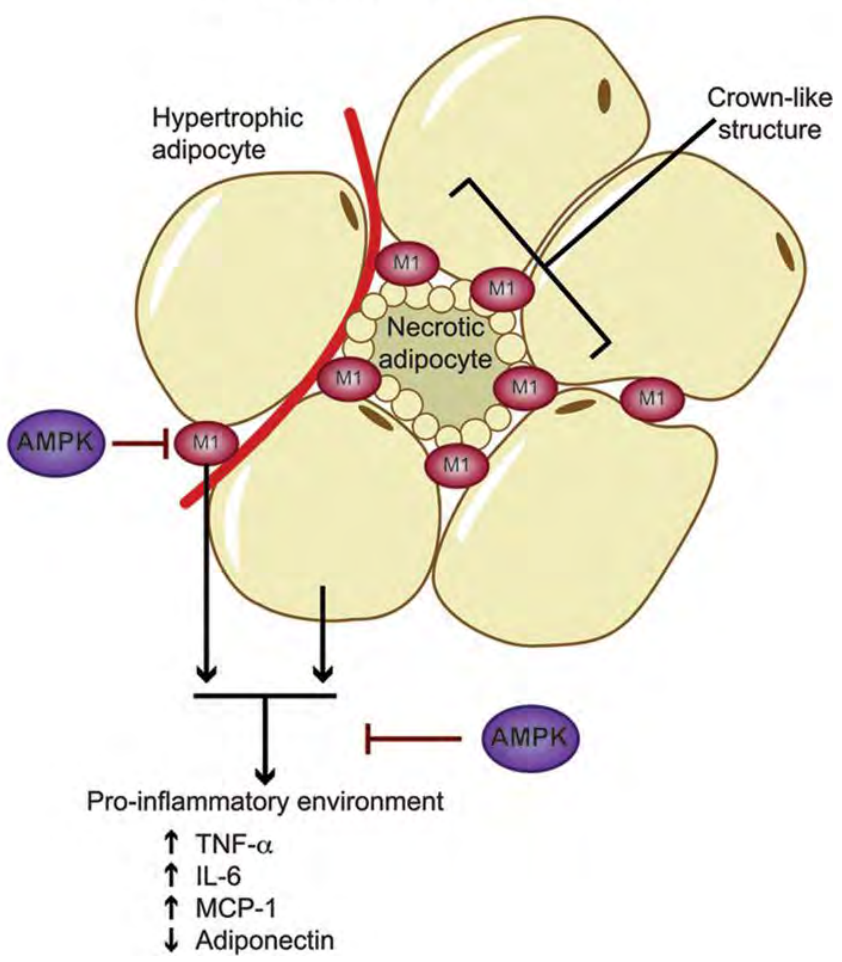

Figure 20. Schematic presentation of adipose tissue. The "big" (hypertrophied) adipocytes. The yellow formations are fat cells (adipocytes) - left, ,"elegant" adipocytes, right - "fat" adipocytes, the ones that make Homo obesus. From: Tsiloulis T, Watt MJ, Molecular and cellular regulation of adaptation to exercise. In: Progress in Molecular Biology and Translational Science. 2015.

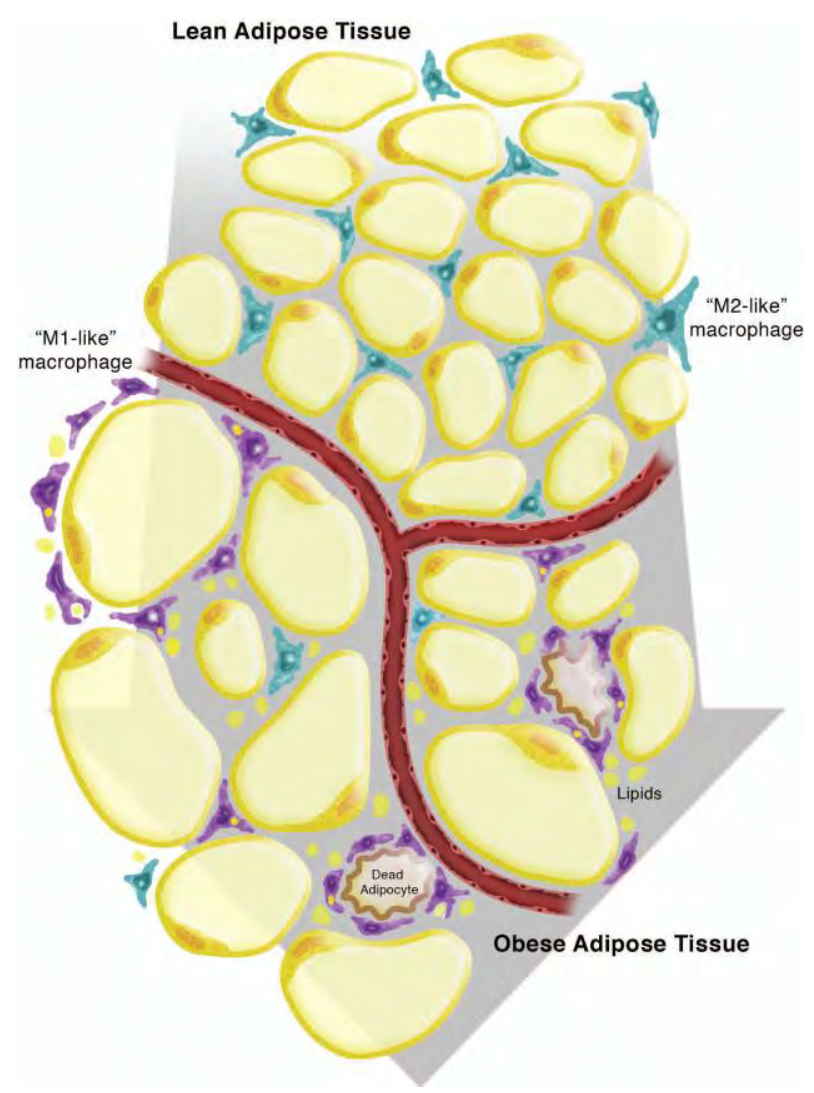

Figure 21. Macrophages in lean and obese adipose tissue. As adipose tissue (AT) transitions from a lean to an obese state, the adipocytes undergo hypertrophy and macrophages numbers increase. The resident macrophages in lean AT are M2-like, and likely play key roles in AT homeostasis. The macrophages in obese AT are M1-like, forming crown-like structures, and secrete proinflammatory cytokines. This leads to local and systemic insulin resistance. From: *Hill AA, Reid Bolus W, Hasty AH. A decade of progress in adipose tissue macrophage biology. Immunol Rev 2014; 262:134-152. DOI:10.1111/imr.12216. Also see *Estefania G-F, et al. High-intensity interval training reductrion of crown-like structures in adipose tissue (Abstract). Adipobiology 2019;10:79. 


\section{Big question: how to reverse this pathway? HOMO SANUS > HOMO OBESUS > HOMO DIABESUS}

In 2001, the World Health Organization (WHO) stated that there was a brand new pandemic of "globesity" and related diseases (Table 15) sweeping the world.

Table 15. A selected list of cardiometabolic diseases

\section{Cardiovascular diseases}

Atherosclerosis, Hypertension

Acute coronary syndromes (coronary heart disease)

Atrial fibrillation

Congestive heart failure (the heart can't pump enough blood to other organs)

\section{Cerebrovascular diseases}

Stroke - ischemic and hemorrhagic

Vascular dementia

\section{Metabolic diseases}

Obesity, Metabolic syndrome

Type 2 diabetes mellitus

- Diabetic neuropathy

- Diabetic retinopathy

- Diabetic erectile dysfunction

Type 3 diabetes (Alzheimer's disease)?

Invest in biomedical research to improve health (appeal of the Bulgarian Society for Cell Biology).

Invest in health to improve wealth (appeal of the World Health Organization).

Projections through 2035 (data of the American Heart Association and the American Stroke Association):

In 2015, 41.5 percent (102.7 million) of the USA population had at least one cardiovascular diseases (CVD):

High Blood Pressure

Coronary Heart Disease (CHD)

Stroke

Congestive Heart Failure (CHF)

Atrial Fibrillation

In 2035, the number of Americans with CVD is projected to rise to 131.2 million - 45 percent of the total USA population. This means additional increases of medical costs.
High Blood Pressure

Coronary Heart Disease

Stroke

Congestive Heart Failure

Atrial Fibrillation
96.1 million 16.8 million 7.5 million 5.8 million 5.2 million
Figure 22. Basic structure of lipid droplet (liposome, adiposome). From: Onal G, et al. Lipid droplest in health and disease. Lipids in Health and Disease 2017;16:128. DOI 10.1186/ s12944-017-0521-7

Recent advances in lipidomics and proteomics technology offer students and scientists a more complex understanding of MSF of LD. Many structural and functional proteins are identified and characterized on the surface of this "rediscovered” organelle ( ${ }^{\star}$ BasuRay S. Protein turnover in lipid homestasis. Adipobiology 2017, 9: 9-17). Some of them are listed in Table 16. 

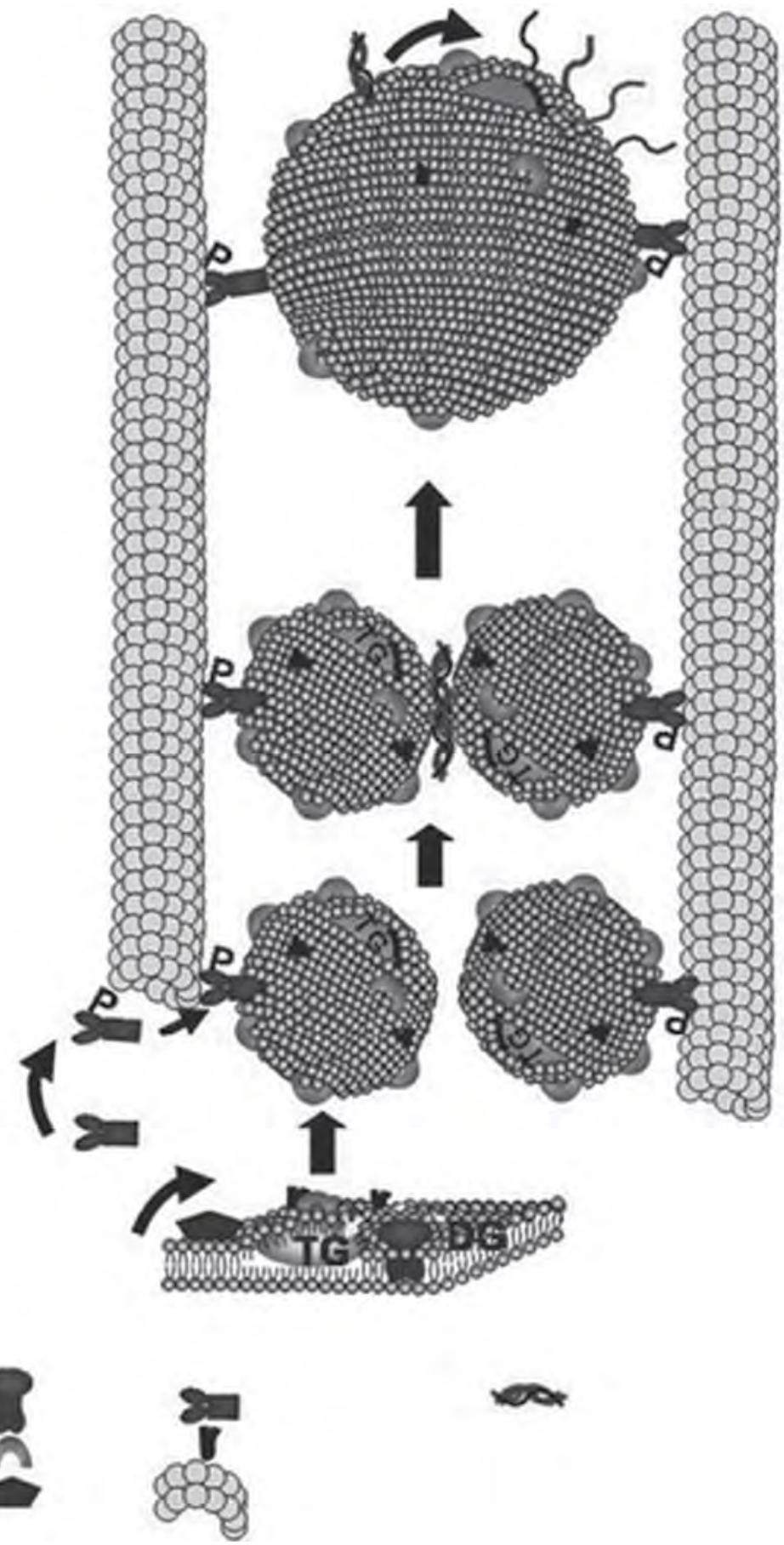

Figure 23. Shematic presentation of the formation of liposomes. Triglycerides (TG) and diglycerides (DG) accumulate between the phospholipid layers of the membrane of smooth endoplasmic reticulum - then, detached from it, and move along the wall of two microtubules using dynein motor protein, and fuse each other with the participation of the fusogenic molecules Soluble NSF (N-ethylmaleimidesensitive factor) accessory protein receptor (SNARE, SNAP23) and syntaxin-5. In effect, a vacuole containing TG and DG covered by single phospholipid layer is delivered - the liposome (adiposome). From: C. Ehnholm, editor. Cellular Lipid Metabolism. SpringerVerlag Berlin Heidelberg. 2009. DOI 10.1007/978-3642-00300-4_1.

Table 16. Predominant surface proteins of lipid droplets (LD)

- Perilipin-1 (PLIN-1), a protein that regulates the access of lipases to lipids in the core of LD.*

- Adipocyte differentiation-related protein (ADRP; also called adipophilin)**

- TIP47 (tail-interacting protein of $47 \mathrm{kD}$ ) ${ }^{* * * *}$.

**Itabe H, Yamaguchi T, Nimura S, Naoko Sasabe. Perilipins: a diversity of intracellular lipid droplet proteins. Lipids Health Dis 2017; 16: 83. doi: 10.1186/s12944-0170473-y

***Listenberger LL, Ostermeye-Fay AG, Goldberg EB, Brown WJ, Brown DA. Adipocyte differentiation-related protein reduces the lipid droplet association of adipose triglyceride lipase and slows triacylglycerol turnover. J Lipid Res 2007. 48:2751-2761.

****Bulankina AV, Deggerich A, Wenzel D, Mutenda K, Wittmann JG, Rudolph MG, Burger KN, Höning S. TIP47 functions in the biogenesis of lipid droplets. J Cell Biol 2009;185(4):641-655. DOI 10.1083/jcb.200812042. 
Food for thought-4: May Alzheimer's pathology spread from the adipose tissue to the brain?

- De la Monte SM, Wands JR. Alzheimer's disease is type 3 diabetes - evidence reviewed. J Diabetes Sci Technol 2008; 2: 1101-1113.

- Lee YH, et al. Amyloid precursor protein expression is upregulated in adipocytes in obesity. Obesity (Silver Spring) 2008;16:1493-500. DOI: 10.1038/oby.2008.267.

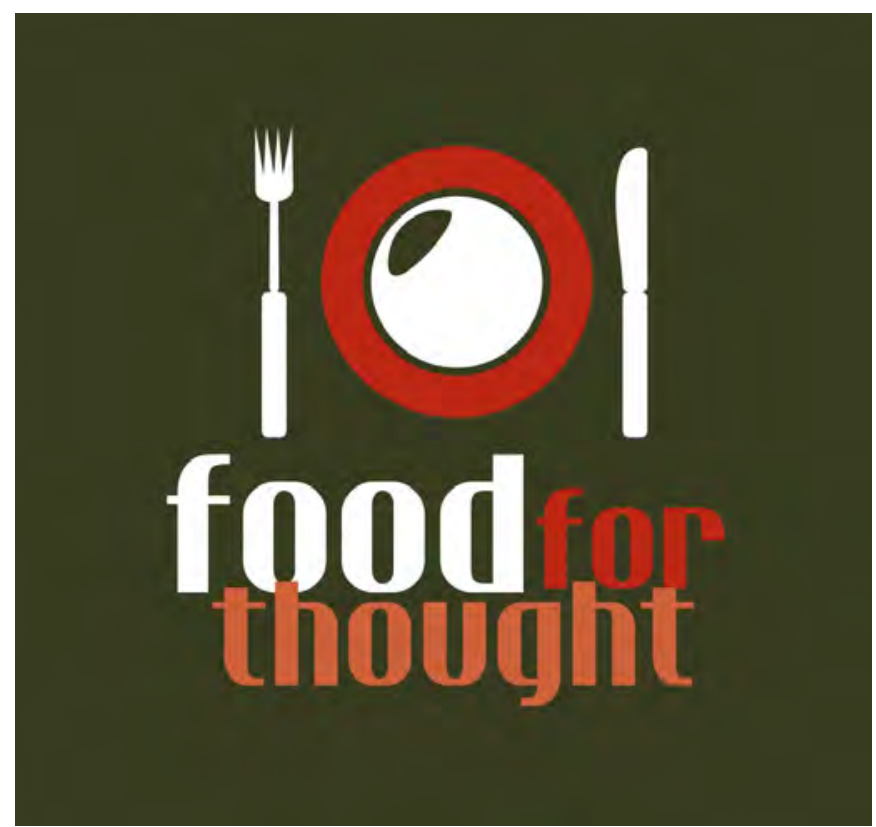

Figure 24. This dish looks like white adipocyte surrounding by plasmalemma (black circle) and having unilocular lipid droplet (white), a marginally located nucleus (black), and basal lamina (red).

\section{REPETITIO EST MATERSTUDIORUM}

Cells-and-matrix is the structural-molecular-functional (MSF) unit of multicellular life

Focal adhesion contacts (FAC) is presented as an example of the integrity of cell-and-matrix. FAC together with focal adhesion kinase (FAK) acts as a molecular motor necessary for cell movement, also a biomechanical sensor (e.g. in durotaxis - cell's "tactile feeling" of ECM rigidity, which controls cell migration and stiffness-dependent structural changes) (Fig. 25; also see Fig. 3, 4).

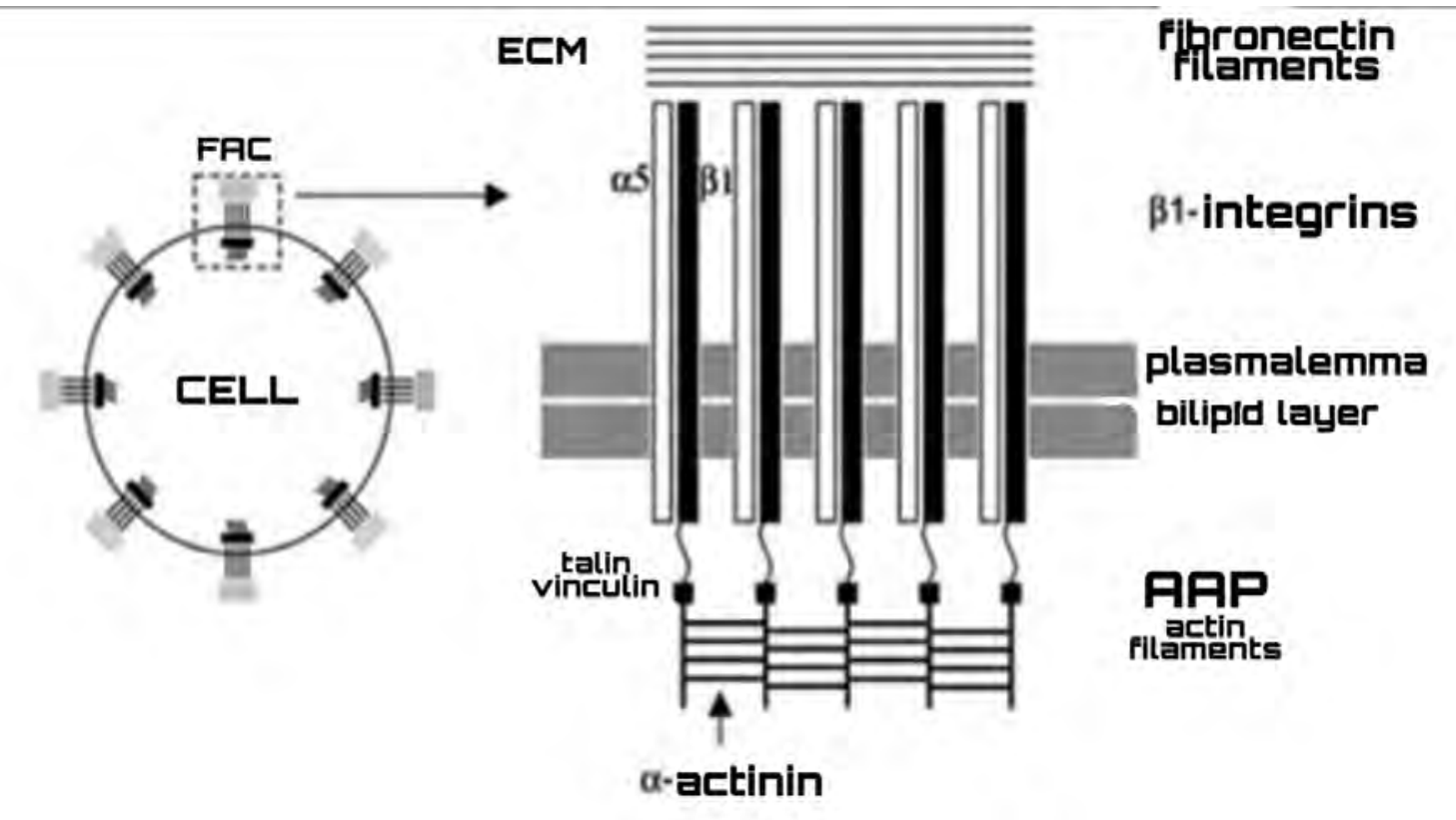

Figure 25. Scheme of focal adhesion contact (FAC). ECM, extaracellular matrix, AAP, actin-associated proteins. From: Chaldakov GN. Cell Biology $2^{\text {nd }}$ edition. 2014. 
Receptor-mediated signal transduction, one of the major functions of plasmalemma (Fig. 26, 27)

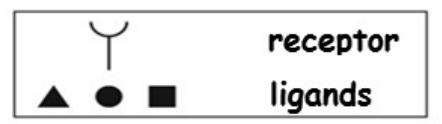

Figure 26. Scheme of receptor-ligand interaction mediating the signal transduction. From: Chaldakov GN. Cell Biology $2^{\text {nd }}$ edition. 2014.
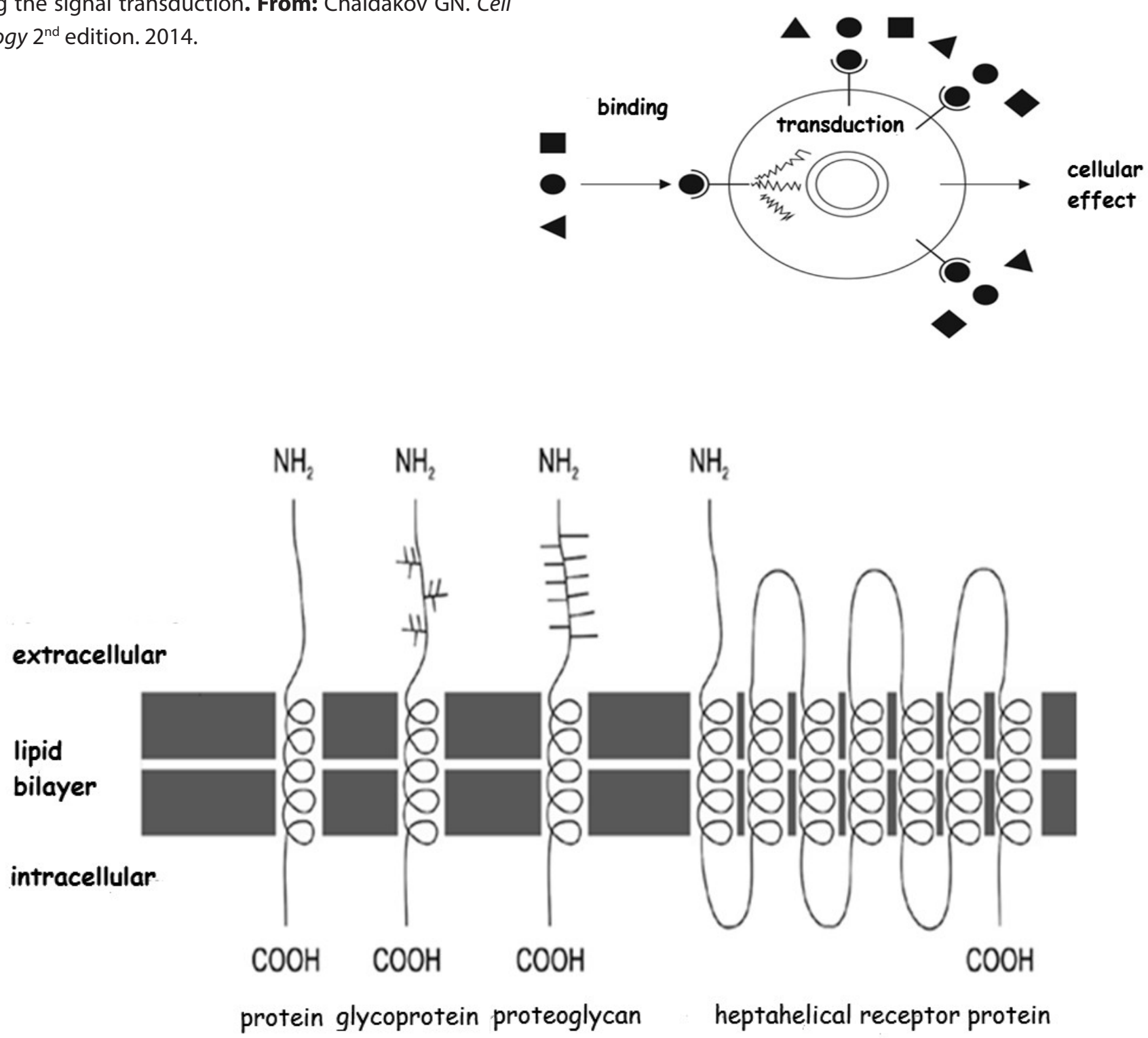

Figure 27. Schematic presentation of plasmalemmal receptors. G-protein-coupled receptors (GPR or GPCR) - receptors linked to G-protein, G standing for guanosine triphosphate (GTP - guanosine triphosphatases). GPR are heptahelical transmembrane (7TM) proteins; briefly, GPR are 7TM proteins. GPR are superfamily consisted of approx. 1000 members, 350 of them for endogeneous ligands: hormones, chemiokines, prostanoids, neurotransmitters (adrenalin, noradrenalin, serotonin, dopamine, ATP, ADP, adenosine), fatty acids, canabionoids, etc. For 150 GPR the respective ligands are not yet known, hence dubbed orphan receptors. Still other GPR are for exogenous ligands: photons, sounds, taste, odorants - these GPR mediate vision, hearing, taste, and sense of smell (olfaction), respectively. For their Eureka studies on G-proteins and their role of receptor-mediated signal transduction Alfered Gilman and Martin Rodbel received Nobel Prize for 1994. In 2012 Brian Kobilka and Robert Lefkovits were arwarded Nobel Prize for GPRs.

In KISS, GPR are the most numerous cellular receptrors, which regualate a diverse spectrum of cell functions in health and disease. Today, many drugs are anatagonists (inhibitors) or agonists (stumulators) of GPRs. 
Food for thought-5: Knockout (KO) versus wild ("OK") mice Leptin, ob/ob (-/-) KO mice becoming obese (Fig. 28)

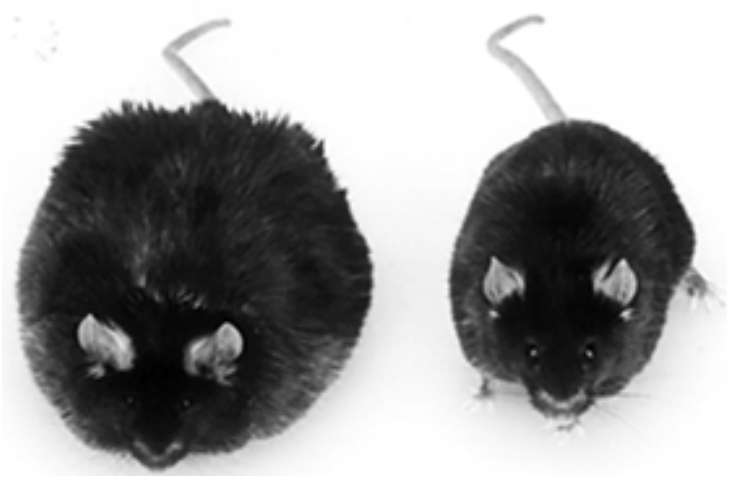

Figure 28. Leptin, $o b / o b(-/-)$ knockout mice getting obesity phenotype (mice at the left).

\section{Food for thought-6: there are many 0mic- fields of research}

- Human organism has 200 different cell types and atotal of approx. 100 trilion cells.

- Human genome has apparox. 25000 genes encoding more than 300000 different proteins.

- Human connectome has 100 bilion nerve (neural) cells, each of them making 10000 synaspses (and autapses) meaning 500-1000 trilion synapses in the human brain.

- Human microbiome has about 50 trilion bacteria (an exteriorized organ with endocrine and paracrine function involved in health and disease) and 100 times more genes than human genonome.

- Human virome (incliding bacteriophages) has about $8 \%$ of the human genome.

- Superorganism, a collection of human, bacterial and viral genes - what is the human?

\section{Food for thought-7: ARISTOTLE'S (and Chaldakov's) didactics:}

"Educating the mind without educating the heart is no education at all."

Also see ${ }^{\star}$ Building a Better Physician - The Case for the New MCAT - Medical College Admission Test published on 5 April 2012 in New England Journal of Medicine.

\section{Food for thought-8: Microglial adipobiology}

${ }^{*}$ Marin D. Zhelezov. Microglial adipobiology: A new concept for understading the adipose tissue-brain crosstalk in health and disease. Adipobiology 2019;10:25-40

\section{Food for thought-9: Cognitive adipobiology}

- Puig KL, et al. Amyloid precursor protein and proinflammatory changes are regulated in brain and adipose tissue in a murine model of high fat diet-induced obesity. PLoS One 2012; 7:e30378. DOI:10.1371/journal.pone.0030378.

- De la Monte SM, Wands JR. Alzheimer's disease is type 3 diabetes - evidence reviewed. J Diabetes Sci Technol 2008; 2 : 1101-1113.

- Chaldakov GN. The cognitive adipobiology: A gold mine to be unfolded (abstract). Adipobiology 2019;10:66.

- 5th ISAA Cognitive Adipobiology George Chaldakov PART 1 https://www.youtube.com/watch?v=QrXLA4UsQnw

- 5th ISAA Cognitive Adipobiology George Chaldakov PART 2

https://www.youtube.com/watch?v=a36MeFO1L8I

The MERIDA $5^{\text {th }}$ ISAA, 1 - 4 May, 2019

The Cognitive Adipobiology:

A Gold Mine to be Unfolded

Georee N. Chaldakov, Luigi Aloe, Marcia Hiriart.

Marco Fiore, Stanislav Yanev, Marin Zhelezov

https://youtu.be/bHLaWoOm2wY

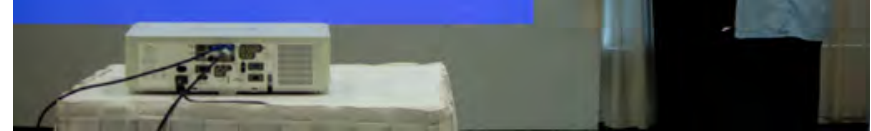

\section{Caesar:}

Let me have men about me that are fat,

Sleek-headed, and such as sleep a-nights:

Cassius has a lean and hunger look;

He thinks too much: such men are dangerous. ${ }^{*}$

William Shakespeare

Julius Caesar, Act I, Scene 2

* A link to cognitive adipobiology.

\section{Epilogue}

Search, visit, and read science papers using the following data base platforms:

- PubMed/Medline

- Scopus (https://www.scopus.com)

- Digital object identifier (DOI)

- ResearchGate (http://www.researchgate.net)

- Online Mendelian Inheritance in Man (OMIM) - online catalogue for human genes and genetic diseases.

- http://press.mu-varna.bg - Medical University of Varna Press (MUV Press) to read Biomedical Reviews, Adipobiology, Scripta Scientifiac Medica and other journals..

- YouTube - also see below. 


\section{CODA}

To a man who knows nothing,

Mountains are mountains

Water is water and

Trees are trees.

When he has studied and knows a little,

Mountains are no longer mountains

Water is no longer water and

Trees are no longer trees.

When he has thoroughly understood,

Mountains are again mountains

Water is water and

Trees are trees.

\section{Zen epigraph}

Hopefully, the present CME would be appreciated by the curious (lyuboznatelni) readers. Herein, I have introduced "scaffolding" as a metaphor that describes the way a teacher provides assistance to the students during the learning process in much the same way that the construction scaffolding serves as a temporary support until the building can stand on its own, which, in terms of neurocognition, is conceptualized as scaffolding theory of aging and cognition (* Park DC, Reuter-Lorenz P. The adaptive brain: aging and neurocognitive scaffolding. Annu Rev Psychol 2009;60:173-196. * Goh JO, Park DC. Neuroplasticity and cognitive aging: the scaffolding theory of aging and cognition. Restor Neurol Neurosci 2009; 27: 391-403).

\section{Dissemination-of-knowledge (DOK)}

Today, a plethora of publications is disseminating globally. In a "think globally-act locally" manner, each of us, mostly in a group with others, focuses - for good or not so much good - on her/his research interest. It is our view that this has brought us only from stage 1 to stage 2 in terms of the three stages of knowledge presented by Zen epigraph, written by Oscar Hechter (1917-2003), the great scientist in steroid hormones research $\left({ }^{*}\right.$ Hecther O, Halkerston IDK. On the action of mammalian hormones. In: The Hormones. Volume 5, Academic Press Inc., New York, 1964. pp 697-816).

\section{Acknowledgments}

Plato learned from Socrates, Aristotle - from Plato, Alexander the Great - from Aristotle, Nietzsche - from Dostoevsky, Luigi Aloe - from Rita Levi-Montalcini, Marco Fiore - from Luigi Aloe, Hristo Photev - from Ivan Peytchev, Petya Dubarova from Hristo Photev...
The author of the present CMC - from his parents, teachers and BHFs, including the family. For discussions and the noosphere (Greek, nous - mind, which, according to Plato, leads to the soul) before and during the preparation of the present "lecture" I should like to express my indebtedness to all of them. I am also grateful to my former and present students.

\section{Magister Dixit (the teacher has said)}

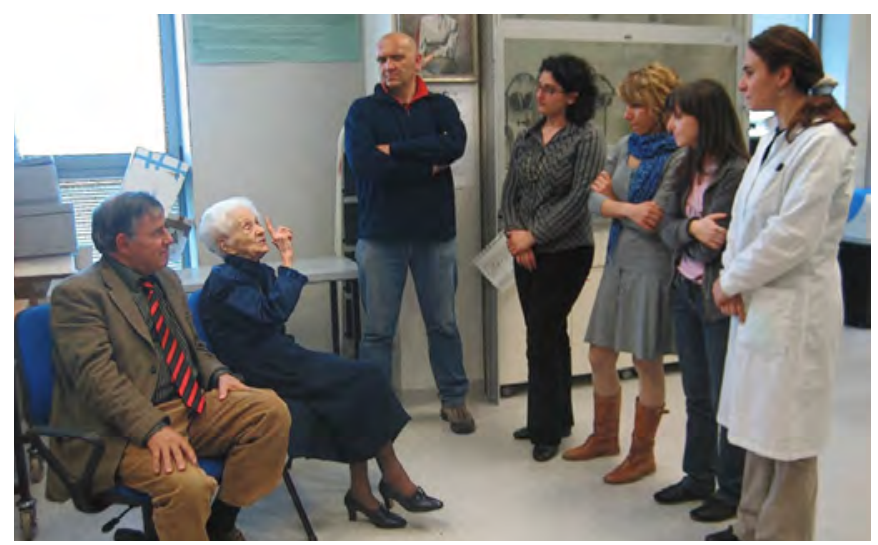

Rita Levi-Montalcini and Luigi Aloe with their collaborators in the Institute of Cell Biology and Neurobiology, CNR, Rome, Italy.

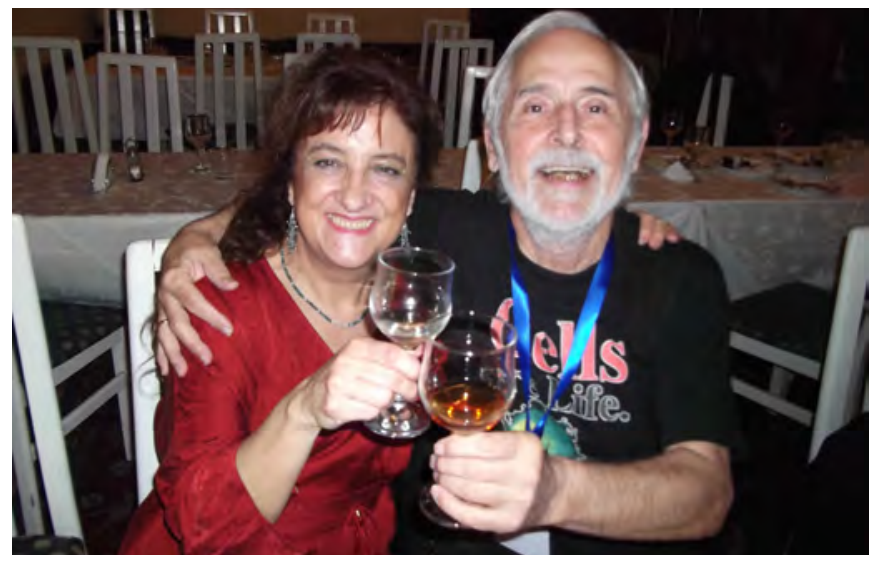

With Marcia Hiriart at $4^{\text {th }}$ International Symposium on Adipobiology and Adipopharmacology (ISAA) held on 28-31 October 2015 in Bucharest, Romania, the organizer of $5^{\text {th }}$ ISAA in Merida, Yuctan, Mexico in $2019\left({ }^{*}\right.$ Hiriart M, Fiore M, Chaldakov GN. Save the obese man (SOS for Homo obesus). Effective adipopolitics and adipoeconomics are urgently required. Echo of the Fifth International Symposium on Adipobiology and Adipopharmacology (ISAA), 1-4 May 2019, Merida, Yucatan, Mexico. Adipobiology 2019; 10:113-118. 
- 5th ISAA Opening Ceremony Marcia Hiriart https://www.youtube.com/watch?v=rXfIJE4IyF0

- 5th ISAA Opening Ceremony George Chaldakov https://www.youtube.com/watch?v=g_jYmdsc4FQ
- 5th ISAA Opening Ceremony Nikifor Chaldakov https://www.youtube.com/watch?v=BshPVzlPZ4E

- 5th ISAA Declaration of BHF Closing Ceremony https://www.youtube.com/watch?v=pULf_hmzMlQ 